NBER WORKING PAPER SERIES

\title{
ACCESS AND USE OF CONTRACEPTION AND ITS EFFECTS ON WOMEN'S OUTCOMES IN THE U.S.
}

\author{
Martha J. Bailey \\ Jason M. Lindo \\ Working Paper 23465 \\ http://www.nber.org/papers/w23465
NATIONAL BUREAU OF ECONOMIC RESEARCH
1050 Massachusetts Avenue
Cambridge, MA 02138
June 2017

Prepared for inclusion in the Oxford Handbook on the Economics of Women, ed. Susan L. Averett, Laura M. Argys, and Saul D. Hoffman (New York: Oxford University Press. Forthcoming, 2018). We are grateful to the editors for suggestions and Rachel Baccile for excellent research assistance. We gratefully acknowledge the use of the services and facilities of the Population Studies Center at the University of Michigan (funded by NICHD Center Grant R24 HD041028). The views expressed herein are those of the authors and do not necessarily reflect the views of the National Bureau of Economic Research.

NBER working papers are circulated for discussion and comment purposes. They have not been peerreviewed or been subject to the review by the NBER Board of Directors that accompanies official NBER publications.

(C) 2017 by Martha J. Bailey and Jason M. Lindo. All rights reserved. Short sections of text, not to exceed two paragraphs, may be quoted without explicit permission provided that full credit, including (C) notice, is given to the source. 
Access and Use of Contraception and Its Effects on Women's Outcomes in the U.S.

Martha J. Bailey and Jason M. Lindo

NBER Working Paper No. 23465

June 2017

JEL No. I12,I13,I18,J1,J13,J18,N32

\section{$\underline{\text { ABSTRACT }}$}

Changes in childbearing affect almost every aspect of human existence. Over the last fifty years, American women have experienced dramatic changes in the ease and convenience of timing and limiting childbearing, ranging from the introduction of the birth control pill and the legalization of abortion to more recent availability of long-acting reversible contraceptives (LARCs). This article chronicles these changes, provides descriptive evidence regarding trends in use, and reviews the literature linking them to changes in childbearing and women's economic outcomes.

Martha J. Bailey

University of Michigan

Department of Economics

611 Tappan Street

207 Lorch Hall

Ann Arbor, MI 48109-1220

and NBER

baileymj@umich.edu

Jason M. Lindo

Department of Economics

Texas A\&M University

4228 TAMU

College Station, TX 77843

and NBER

jlindo@econmail.tamu.edu 


\section{Changes in Contraceptive Technology, Rights, and Access in the U.S., 1900-2016}

Today, a variety of highly effective contraceptive methods, scientifically tested and U.S. Food and Drug Administration (FDA) approved, are widely available either by prescription or over the counter. Manufacturing and selling contraceptives is legal in all 50 states, and federal and state governments and nonprofit and private organizations subsidize family planning services.

Just fifty years ago, contraceptives and information on contraception were considered obscene and banned under federal and many state statutes. Many of these bans date back to the federal Comstock Act, ${ }^{1}$ passed in 1873, which outlawed the interstate mailing, shipping, or importation of articles, drugs, medicines, or printed materials considered "obscenities"-a term referring to anything used "for the prevention of conception" (18 U.S.C. §1461-1462). In the wake of the Comstock Act, 45 states passed or amended anti-obscenity statutes mentioning contraception (Bailey 2010).

The implications of this legislation were broad. One large-scale survey revealed that only 10 percent of physicians earning a medical degree before 1920 received any medical school training on contraception (Guttmacher 1947). Instead, information (and misinformation) about contraception flowed through families, friends, and often charlatans. Sexually transmitted diseases were rampant before the introduction of penicillin and wide-ranging public health awareness campaigns (Brandt 1985). Many undesired pregnancies were terminated by abortion, which was illegal and dangerous.

\section{A. The Birth Control Movement}

Margaret Sanger is typically credited with beginning the U.S. birth control movement. One of the movement's successes was that the U.S. Second Circuit Court of Appeals struck down portions of the Comstock Act in U.S. v. One Package (86 F.2d 737, 1936). In 1937, the American Medical Association (AMA) reversed its longstanding opposition to birth control.

\footnotetext{
${ }^{1}$ The act takes its name from its zealous advocate, Anthony Comstock of New York.
} 
Public opinion polls show a strong increase in popular support during this time. Figure 1 shows that, in 1936, when the Gallup Poll first asked respondents whether they "favor the birth control movement," 61 percent answered affirmatively (13 percent did not answer). In 1938, Gallup fielded a new question about whether respondents "would like to see a government agency furnish birth control information to married people who want it." The share of affirmative answers increased from about 62 percent of the nation's adults in 1938 to 67 percent in 1947. And in 1959, 73 percent of Gallup respondents said that "birth control information should be available to anyone who wants it."2 Thus, during the two decades leading up to the introduction of "the Pill" - an era noted for its large baby boom and pronatalist policies - public support for government provision of birth control information was high and increasing.

Although the supply of condoms and diaphragms increased along with public support, these contraceptives were expensive and often poor quality. Contraceptive failure rates were high, and stigma and misinformation limited the effectiveness of these methods. ${ }^{3}$

\section{B. $\quad$ The Introduction of the Pill and Legal Restrictions on their Sale}

Enovid, the drug that would become the first oral contraceptive, was initially introduced for the regulation of menses in 1957 and was later approved by the FDA for longer-term use as a contraceptive in 1960. Soon known as "the Pill," this oral contraceptive was met with "extraordinary immediate enthusiasm" (Weinberg 1968). In 1965, 25 percent of white married women and 15 percent of nonwhite married women reported having ever used the Pill; by 1973, nearly 65 percent of married women aged 15 to 24 using any contraception chose the Pill (Westoff 1976).

Despite the Pill's growing popularity, Comstock-era obscenity statutes in some states constrained availability. Comstock laws had been difficult to enforce for barrier methods like diaphragms and condoms,

\footnotetext{
${ }^{2}$ The full question reads, "In some places in the US it is not legal to supply birth control information. How do you feel about thisdo you think birth control information should be available to anyone who wants it, or not?"

${ }^{3}$ In the 1940s and 1950s, physicians built lucrative practices around filling contraceptive prescriptions in house, and local pharmacists provided "legitimate" supplies at large markups. Although the profitability of selling contraceptives cultivated the support of physicians and increased the social acceptance of these methods, it also increased inequality in access to these methods.
} 
but the Pill was available only from physicians and pharmacists, for whom violating state laws could jeopardize their licenses and livelihoods. Women would have had a hard time verifying the effectiveness of illicitly obtained Pills.

Anti-obscenity statutes were dealt a blow by the 1965 U.S. Supreme Court case Griswold v. Connecticut (381 U.S. 479), which prompted state legislatures to curtail these statutes. By 1970 every state (and the federal government) permitted the sale of contraceptives to married individuals, and the Eisenstadt v. Baird decision (405 U.S. 438) extended this to unmarried adults as well. However, other laws or regulations in some jurisdictions continued to make the purchase of contraceptives difficult. ${ }^{4}$

\section{The Rise of Publicly Funded Family Planning Programs}

The birth control movement next turned its attention to expanding financial access to reliable contraceptives through government-supported "family planning" programs. The argument for subsidizing family planning was based upon the premise that the high cost of contraceptives (and related information and services) tended to keep birth rates high among lower-income individuals. Advocates argued that, just as legal restrictions had inhibited many from obtaining reliable contraceptives, the cost of modern contraceptives differentially inhibited lower-income individuals from using them. ${ }^{5}$

Widespread concern about population growth (Wilmoth and Ball 1992, Wilmoth 1995), together with studies showing that lower-income families were having more children than they desired (National Academy of Sciences 1963), galvanized support for federal intervention. ${ }^{6}$ The first U.S. family planning programs were quietly funded under the 1964 Economic Opportunity Act (EOA), a centerpiece of President

\footnotetext{
${ }^{4}$ See Bailey et al. (2011) for a description of legal changes that expanded access for unmarried minors.

${ }^{5}$ This argument was especially relevant in the early 1960s, when the monopoly producer of Enovid sold it at a premium. Shortly after its release, an annual supply of Enovid cost the equivalent of about $\$ 760$ in 2010 dollars (Tone 2001, p. 257), roughly twice today's annual cost and equivalent to more than 3 weeks of full-time work at the 1960 minimum wage. In 1961 Maurice Saugoff of Planned Parenthood asserted that even his clinic's discounted price (less than half the retail price) was "beyond the reach of many of our low-income inquirers" (Tone 2001, p. 257).

${ }^{6}$ In 1968, 77 percent of adults surveyed nationwide said that birth control information should be available to everyone (Figure 1). The rise in public support tracks fairly closely mentions of birth control, contraception, and family planning in books published over the same period, as measured by Google Ngrams.
} 
Johnson's War on Poverty. ${ }^{7}$ Generally speaking, these programs aimed to bring birth control information and contraceptives to disadvantaged individuals. Federal family planning dollars funded education, counseling, and the provision of low-cost contraceptives and related medical services, but they did not fund abortion - a support model that continues today.

Funding for this program expanded through the late 1960s and culminated with the 1970 enactment of Title X of the Public Health Service Act (also known as the Family Planning Services and Population Research Act, P.L. 91-572 § 1008). This legislation increased federal support of family planning by 50 percent in real terms by 1974. From 1975 to 1980, however, federal appropriations for Title X fell to an average of roughly $\$ 400$ million per year, reaching a low of $\$ 231$ million by 1991 , and averaging around \$300 million since then (all amounts in 2010 dollars). While federal appropriations have continued since the 1960s, many states enacted policies that constrained the operations of family planning clinics. Seven states (Arizona, Arkansas Colorado, Indiana, Ohio, Texas, Wisconsin) have barred access to Title X funds for any clinics affiliated with abortion providers and three more (Kansas, North Carolina, and Oklahoma) have barred access for all private clinics (Guttmacher Institute 2016b). Indiana and Arizona passed legislation to block such clinics from Medicaid funding, though these were deemed illegal in federal court in 2012 and 2013, respectively (Planned Parenthood of Indiana v. Commissioner of the Indiana State Department of Health No. 11-2464, Planned Parenthood of Arizona v. Betlach, No. CV-12-01533-PHXNVW).

\section{The Checkered History of Intrauterine Devices and the New Era of LARCs}

In the late 1920s, Ernest Graefenberg developed the precursor to the modern day intrauterine device (IUD), a flexible ring made of silkworm gut or coiled metal. Although the Graefenberg ring was popular in

\footnotetext{
${ }^{7}$ Before 1965, U.S. federal involvement and investments in family planning had been modest. This reflected the view expressed by President Dwight Eisenhower in 1959, who said that he could not "imagine anything more emphatically a subject that is not a proper political or government activity or function or responsibility... The government will not, so long as I am here, have a positive political doctrine in its program that has to do with the problem of birth control. That's not our business" (Tone 2001, p. 214). According to 1967 estimates, expenditure for family planning through the Maternal and Child Health programs started in 1942 and the Maternal and Infant Care programs under the 1963 Social Security Amendments were small (U.S. DHEW 1974).
} 
England, Canada, and other countries soon thereafter, it did not catch on in the U.S. until much later due to concerns about effectiveness and risk of infection (Hubacher and Cheng 2004). In the early 1960s, new science from around the world began to assuage these concerns (Hutchings et al. 1985), and the first plastic IUD, Gynekoil, was produced and sold to American women. By the end of the 1960s, estimates suggest that around 1 million American women were using IUDs (Hubacher and Cheng 2004).

The popularity of IUDs began to increase in the 1970s, and as makers actively marketed them as a safer alternative to birth control pills (Thomsen 1982). Whereas only 1.2 percent of married women aged 15 to 24 using contraception reported using an IUD in 1965, 9.6 percent reported using an IUD in 1973. A significant share of this increase was driven by the introduction in 1971 of the Dalkon Shield, which sold 2.2 million devices over the following four years (Hicks 1994). Design flaws in the Dalkon Shield, however, turned out to be quite dangerous and appeared to have increased women's risk for pelvic inflammatory disease (PID).

Given the problems, the Dalkon Shield was removed from the market by its manufacturer in 1974 (Hubacher and Cheng 2004) and resulting oversight hearings in both houses of the U.S. Congress and the FDA led to IUDs and other medical devices becoming subject to FDA regulations similar to those for the testing and sale of drugs (Thomsen 1982). The Medical Device Regulation Act of 1976 required that nondrug IUDs (and other "Class III" medical devices) be approved by the FDA before they could be sold.

The Dalkon Shield blemished the reputation of all IUDs, and both use and availability of IUDs fell dramatically in the 1980s (Hubacher and Cheng 2004). Just 7 percent of women using contraception reported using an IUD in 1982 and just 1 percent in 1995 (Mosher and Jones 2010). The controversy surrounding the possibility of elevated risk for STDs, PID, and infertility for IUD users in the 1980s is still evident in attitudes and use of IUDs today.

The 1990s saw the lowest prevalence of IUD usage and only two device options: ParaGard and Progestasert. This started to change in the year 2000, when the FDA approved Mirena. Two new options, Skyla and Liletta, appeared in 2013 and 2015-both marketed to younger, nulliparous women. In 2002, only 2 percent of contraceptive users chose an IUD; by 2009, that number had increased to 8.5 percent and 
by 2013 it increased to 10.7 percent (Finer, Jerman, and Kavanaugh 2012). These changes likely reflect greater awareness and increased affordability under the 2010 Patient Protection and Affordable Care Act (ACA).

An alternative type of contraceptive became available in 2006: the subdermal implant, Implanon. Like IUDs, this device, which is inserted under the skin of a woman's upper arm, prevents pregnancy for several years. It is for this reason that IUDs and implants are often combined in discussions of "long-actingreversible contraceptives" (LARCs).

Though these LARCs have met FDA safety requirements and have failure rates of less than 1 percent annually (versus 9 percent for oral contraceptives), they have been slow to attract users. Just 8 percent of women using contraceptives between 2011 and 2013 chose a LARC method. Low use is typically attributed to lack of awareness of LARC options, misconceptions about the safety of current-generation devices, and high up-front costs. In any case, because they completely eliminate user-compliance error, these LARCs have been promoted as a superior alternative to "traditional methods" like oral contraceptives, especially for adolescents. In fact, the American College of Obstetricians and Gynecologists' Committee on Adolescent Health Care and the American Academy of Pediatrics both have stated that LARC methods should be "first-line recommendations" for all adolescents (Committee on Adolescent Health Care 2012, Ott, Sucato, and Adolescence 2014).

\section{E. The Legalization of Abortion}

In the early twentieth century abortion was illegal in the U.S., outlawed on a state-by-state basis with few exceptions: ${ }^{8} 44$ states allowed abortions for women whose life was at risk; 4 states and the District of Columbia allowed abortions if the woman's life or physical health was at risk; Mississippi allowed abortions in cases of rape or for the woman's life; and Pennsylvania prohibited all abortions. In 14 states,

\footnotetext{
${ }^{8}$ It is less well known that early abortions were not illegal earlier in the $19^{\text {th }}$ century (Reagan 1997). In 1857, the newly created AMA sought to make abortion illegal at any stage of pregnancy. The anti-abortion movement was fueled by public health concerns and nativism: a desire to increase the population of native-born whites in response to increased immigration (Reagan 1997).
} 
obtaining or performing an abortion was a criminal offense (Gold 2003), and although women obtaining abortions were rarely prosecuted, the consequences for providers could be severe (Boonstra et al. 2006). Less well known is that "medically justifiable" abortions were often performed during this period, because childbirth was still a major cause of death for women (Mooney and Lee 1995). As medical technology decreased the risk of childbirth with the introduction of sulfa drugs and antibiotics (Thomasson and Treber 2008, Jayachandran, Lleras-Muney, and Smith 2010), and more doctors began practicing in hospitals (Chung, Gaynor, and Richards-Shubik 2016), legal abortions became much more difficult to access.

Efforts to reform state abortion laws began in the early 1960s with the women's rights movement and other advancements in reproductive health. In 1962, the American Law Institute in its Model Penal Code (MPC) proposed abortion regulations that would make abortion legal not just if the mother's life was at risk, but also if the child would be born with grave physical or mental defect, if the pregnancy resulted from rape or incest, or if the mother's mental or physical health was at risk (The American Law Institute 1962). The 1965 Griswold v. Connecticut decision gave abortion activists the needed constitutional argument: abortions should be granted the same constitutional protection of women's privacy rights as access to contraception (Nossiff 2001). Using the MPC as a guide, Colorado was the first state to reform its abortion law in 1967; by 197213 states had adopted MPC abortion statutes. ${ }^{9}$ Furthermore, four statesNew York (the first, in 1970), Washington, Alaska, and Hawaii-had fully repealed their abortion laws (Gold 2003).

The Roe v. Wade decision made access to legal abortion a constitutional right, holding that a woman has a constitutionally protected right to privacy to obtain an abortion in her first trimester. Legal abortion provided unprecedented insurance against unintended pregnancy and unanticipated circumstances after conception (Levine and Staiger 2002). According to the Guttmacher Institute, nearly a fifth of pregnancies

\footnotetext{
${ }^{9}$ These states are Colorado, California, North Carolina, Georgia, Delaware, New Mexico, Nebraska, Maryland, Arkansas, Oregon, Virginia, South Carolina, and Florida.
} 
ended in abortion during the first year of Roe v. Wade, with this share rising to 30 percent over the next decade before beginning a downward trend (Henshaw and Kost 2008).

In the aftermath of Roe v. Wade, many states restricted access to abortion. By 1989203 such restrictions had been adopted nationwide (Guttmacher Institute 2016a). While the Supreme Court rejected many state efforts, these changes have resulted in a variety of waiting periods (Planned Parenthood of Southeastern Pennsylvania v. Casey, 505 U.S. 833) and parental consent requirements (Bellotti v. Baird 443 U.S. 622). The 1976 Hyde Amendment, in particular, limited the use of federal funding through Medicaid for the use of abortion, and states passed similar restrictions for state Medicaid funds, which were upheld by the Supreme Court in 1980. Eventually, the abortion funding ban extended to any federal funding, including for federal employees' health plans (Salganicoff et al. 2014). From 2011 to 2015, states passed 288 new legal restrictions on abortion access (Guttmacher Institute 2016a). These restrictions include requiring counseling and waiting periods; banning so-called partial-birth abortion; banning abortions later in pregnancy; requiring parental involvement; prohibiting public funding; and passing burdensome, medically unnecessary regulations on abortion providers, known as TRAP (targeted regulation of abortion providers) laws.

Since 2010, efforts to restrict abortion by regulating providers gained traction. These policies include regulating corridor width, procedure room size, affiliations with local hospitals, and licensing requirements (Gold and Nash 2013). For example, Texas' House Bill 2, An Act relating to the regulation of abortion procedures, providers, and facilities; providing penalties, (83(1) Texas State Legislature, H.B. 2) required abortion providers to have admitting privileges at a hospital not more than 30 miles away and required all abortions to be done in ambulatory surgical centers. After the admitting privileges requirement went into effect, nearly half of the abortion facilities in the state shut down. Recent studies estimated a 13 percent decrease in Texas's abortion rate just six months after the law went into effect, and significantly higher hardship (travelling over 50 miles, needing to stay overnight, incurred out-of-pocket expenses $>\$ 100$, etc) for women obtaining an abortion whose nearest clinic had closed (Grossman et al. 2014, Gerdts et al. 2016). Cunningham, Lindo, Myers, and Schlosser (2017) use the variation in access induced by this 
law to estimate the causal effects of distance and a measure of congestion - they find that increasing distance to the nearest abortion clinic significantly reduces abortion rates and also find some evidence that congestion induced by closures reduces abortion rates. The portion of the law requiring providers to have admitting privileges and clinics to meet the standards of ambulatory surgical centers was struck down in the 2016 Supreme Court case Whole Women's Health v. Hellerstedt (Guttmacher Institute 2016b) as an undue burden. While the ACA has expanded insurance coverage along many dimensions, the Hyde Amendment and state regulations continue to restrict the use of federal and state funds, respectively, for abortions. Moreover, the ACA does not require that insurance coverage sold on state insurance exchange marketplaces include abortion coverage. Private insurers can offer abortion coverage in their plans, but they need to ensure federal funds are segregated (Salganicoff et al. 2014). ${ }^{10}$

This tumultuous legal history makes it surprising how little public opinion has changed since 1973. Figure 2 shows only modest reductions in support for abortion over the past four decades. For example, support for "abortion when the woman cannot afford a child" fell from a high of 52 percent in 1974 to 41 percent in 2012. In cases of rape, when the woman's health is at risk, or when the likelihood of serious birth defect is large, abortion support declined by between 8 and 13 percentage-points from their peaks. Just shy of 40 percent of the American public today supports abortion access for any reason, although almost double that number supports abortion access in the case of rape.

\section{F. Emergency Contraception}

Until recently, emergency contraception was limited to various "off-label" products. The "Yuzpe method" of using a combination of oral contraceptives to prevent pregnancy dates back to the 1970s (Yuzpe et al. 1974). Copper IUDs, which can prevent pregnancies when inserted soon after unprotected intercourse,

\footnotetext{
${ }^{10}$ In 2014, only two of the 150 multi-state insurance plans offered through the marketplaces covered abortions for circumstances beyond the Hyde Amendment; these plans were only available in Alaska (Archuleta 2013). For women uninsured prior to 2014 (when the ACA went into effect), more than one third live in a state that limits abortion coverage either through Medicare or private plans, and 14 percent do not have access to either Medicare coverage or subsidies for a private plan, leaving them without access to affordable coverage at all (Salganicoff et al. 2014).
} 
have also been available since the 1970s. But in 1999, the FDA approved Plan B - a prescription drug for emergency contraception.

In subsequent years vigorous debates ensued on whether Plan B should be available without prescription and, if so, the degree to which such access should be extended to minors. In December 2003, a joint advisory committee, comprised of the FDA's Nonprescription Drugs Advisory Committee and Reproductive Health Drugs Advisory Committee, recommended the approval of an application for overthe-counter use of Plan B. In May 2004 the FDA went against the committee's advice and rejected the application, citing an insufficient number of subjects in the clinical trial for the drug to be deemed safe for women aged 16 and younger. This decision was followed by a series of amended applications to the FDA to make Plan B available over-the-counter to minors (for different age cutoffs), federal court orders, and a Department of Justice appeal before the FDA implemented the original advisory committee recommendations and made over-the-counter emergency contraception available without an age restriction.

\section{Contraceptive Use and Related Outcomes in the U.S., 1973-2015}

Documenting trends in contraceptive use over time is difficult, because national surveys have only very recently begun collecting this information. ${ }^{11}$ The statistics presented in this section rely on the National Survey of Family Growth (NSFG), which was first conducted in 1973 when it focused on current or previously married women and never married women with children. In 1982 the NSFG began collecting data from all women, regardless of their marital status or childbearing history. ${ }^{12}$

\footnotetext{
${ }^{11}$ In part due to taboos about reporting sexual activity and contraception before the sexual revolution, the 1955 and 1960 Growth of American Families study (GAF) asked only currently married white women ages 18 to 39 about their contraceptive use, marital histories, and childbearing. In 1965 and 1970, the National Fertility Study (NFS) extended the GAF sample to include a more diverse set of race/ethnicities. In 1965 the NFS sampled only currently married women through age 55, and in 1970 the NSF added women who had been married but were no longer married.

${ }^{12}$ Aggregate statistics produced from these NSFG data by marital status, age, race, education, income are available on the authors' websites. Note that the NSFG changed from periodic to continuous sampling beginning in 2006. For simplicity and precision, we aggregate the data by "survey version." This entails grouping NSFG data collected from three different surveys conducted from 2006-2010, 2011-2013, and 2013-2015. We use the middle year for time-series plots.
} 


\section{A. Changes in the Use of Any Contraception}

Figure 3 depicts how the fraction of women using some form of contraception has evolved over time. ${ }^{13}$ Despite the dramatic changes in the available contraceptive technology, laws, and family planning programs, the time-series are remarkably stable. Among married women, nearly 70 percent used some form of contraceptive from 1973 to 1982; in 1988 this number rose to around 75 percent, where it has remained in subsequent years. The share of unmarried women using contraception rose between 1982 and 1988, from 35 to 42 percent, and further increased into the mid-1990s, when 47 percent were using contraception.

Panel A of Figure 4 shows this series by income level. ${ }^{14}$ In the late 1980 s, women with relatively low levels of income were less likely to use contraception than other women. Between 1988 and 1995, however, this gap completely closed despite declining federal appropriations for Title X.

Panel B shows that the gap between the contraceptive-use rates among non-Hispanic whites relative to non-Hispanic blacks and Hispanics did not close over this period and remains today, with approximately 65 percent of non-Hispanic whites using some form of contraception versus approximately 55 percent for non-Hispanic blacks and Hispanics.

Finally, Panel D shows that young women were the least likely of the three age groups to use contraception, though this gap closed somewhat between 2008 to 2014, with the share of 15 to 24 year-olds using contraception growing from 44 percent to 50 percent and the share falling for somewhat for older women.

\section{B. Changes in the Type of Contraceptive Method Used}

Figure 5 shows that the stability of these time-series mask dramatic shifts in the primary type of contraceptive method used. Birth control pills have been the most commonly used form of primary

\footnotetext{
13 Women are classified as using contraception if they are using a method to try to avoid pregnancy or if they (or their husband/partner) had a sterilizing operation "at least partly so that they would not have any more children." Women classified as not using contraception include those seeking pregnancy, those who are pregnant or postpartum (last pregnancy terminated within 2 months of the interview), those who are sterile (for reasons not relating to elective procedures like hysterectomy), and those not using contraception for other reasons.

${ }^{14}$ Figures instead stratifying on completed education among women age 22-44 show similar patterns.
} 
contraception since the early 1970s. After concerns about the Pill's safety were aired in Senate hearings in 1970, the share of women using the Pill as their primary form of contraception fell significantly from 1972 to 1982 , declining from 36 percent to 20 percent among married women (Panel A, a group surveyed consistently over the period). This decline in Pill use was fully offset by increases in other methods, and almost entirely by increases in female sterilization, which increased from 27 percent to 42 percent from 1972 to 1982 (Panel B). ${ }^{15}$ The use of other methods among married women changed little over this period.

The popularity of female sterilization peaked in the 1988 survey wave, when 27.5 percent of all women using contraception and 37.8 percent of married women using contraception were sterilized. Sterilization as a share of primary contraception has changed little since then, though the most recent waves of data suggest that its use may be falling. Panels C and D - focusing on all women ages 15 to 44 and, beginning in 1982 - show broad trends that are similar to those observed among married women. A key trend over this period is growth in the use of LARCs (IUDs and implants), which have been the focus of major advocacy efforts in recent years.

\section{Changes in LARC Use}

Figure 6 examines the recent growth in LARC use in greater detail. The use of LARC has grown similarly across income levels — despite the fact that LARCs often involve high out-of-pocket costs (Panel A). There are some systematic gaps by race/ethnicity and age, however. Rates of LARCs use have been persistently higher for Hispanics than non-Hispanics (Panel B). The pattern by age is interestingly nonmonotonic. Specifically, LARC use has grown very similarly for women aged 15-24 and those aged 35-44; the most dramatic growth has been for women aged 25-34 (Panel C).

\footnotetext{
${ }^{15}$ In results not shown here, we have further investigated heterogeneity in female sterilization rates across these survey years. Perhaps not surprisingly, the largest increases were for older women, aged 35-44. Rates also increased for women aged 25-34. Rates changed little for women aged 15-24. Increases were also evident across all of the education, income, and race/ethnicity groups considered in Figure 4.
} 


\section{Changes in the Use of Emergency Contraception}

In Figure 7 we show how the use of emergency contraception has evolved since 1995. The initial data points are non-zero, highlighting that emergency contraception was possible through off-label use of birth control pills prior to the FDA approval of Plan B in 1999. Still, only 0.8 percent of women aged 15 44 reported ever using emergency contraception in 1995. After Plan B was approved and access increased over time, this number grew, reaching 21.9 percent by 2014. Rates of use have been very similar across groups defined by income (Panel A) and by race and ethnicity (Panel B). However, dramatic differences can be seen across age groups (Panel C). Specifically, increases in ever using emergency contraception have been especially large for young women. Since the share ever using emergency contraception can only grow over time for any given cohort, this feature of the data highlights that emergency contraception has become increasingly important for more-recent cohorts of women.

\section{E. Changes in the Use of Abortion}

The share of women ages 15 to 44 reporting that they ever had an abortion has risen and fallen since the 1982 wave of the NSFG. Specifically, 9.9 percent of women reported ever having an abortion in 1982 and this share rose to 11.6 and 16.6 percent in the 1988 and 1995 surveys, respectively. The share has fallen in all subsequent surveys, reaching a low of 11.2 percent in 2014.

In Figure 8 we present abortion statistics for selected subgroups. Panel A shows that similar shares of women reported ever having an abortion across income groups - both in 2014 and in other surveys going back to 1982. Panel B shows the divergence between non-Hispanic black and non-Hispanic white women, with the gap in the likelihood of ever having an abortion growing from just 2-3 percentage points more for black women in 1982 and 1988 , to nearly 6 percentage points in 1995, to 8 percentage points in 2002 , to more than 10 percentage points in 2014. For Hispanics, the data do not show consistent evidence that their rates have been systematically higher or lower than non-Hispanic whites in earlier or later survey waves.

Panel $\mathrm{C}$ shows the share of women reporting abortions across three age groups. The share of young women (aged 15-24) reporting having had an abortion has fallen steadily from 7.5 percent in 1982 to 4.0 
percent in 2014. We see the rise and fall in women reporting abortions mentioned above for women aged 25-34 and, in a less pronounced way, for women aged 35-44. Perhaps most notably, the share of women reporting an abortion has declined in all age groups since 2002 .

\section{F. Changes in Childbearing}

Before discussing changes in childbearing, we briefly recap several important patterns in birth control use. Beginning in 1960, the Pill rapidly emerged as the most popular method of contraception and has remained 25 to 30 percent of users' choice of primary method. Second, condoms became increasingly popular as a primary contraceptive between the early 1980s and the mid-1990s with the rise of the HIV epidemic, but have declined steadily in recent years. Third, the diaphragm was used less and less over the 1980s and 1990s and is presently used by less than one percent of women who use contraception. Fourth, the IUD has recently experienced a resurgence and is now rapidly approaching the popularity of the condom and the Pill. Fifth, the number of women who have used emergency contraception has grown considerably since Plan B was approved in 1999. Sixth, the share of women reporting having had an abortion rose until the mid-1990s and has since fallen.

Evaluating how shifts in contraceptive technology, access, and use have affected childbearing or other outcomes is complicated by the dramatic changes in childbearing both before and after 1960. Figure 9 shows that the baby boom - a 20 -year period that saw a 50 percent increase in childbearing — shortly preceded the introduction of modern contraception and legalized abortion. By cause or coincidence, the baby boom ended around 1960 and U.S. fertility rates declined to reach half their peak by 1970 (around 65 births per 1000 women of childbearing age). Completed childbearing by age 41 declined from a high of 3.3 children for women born in the mid-1930s (in their mid-twenties at the baby boom's peak) to around 2 children for women born around 1970 (Bailey, Guldi, and Hershbein 2014).

One unique feature of fertility decline in the 1960 s is that a much larger share of women reaching childbearing age after 1960 had exactly two children (35 percent versus 22 percent for the previous generation). Figure 10 plots the shift toward two-child families by birth cohort. As childbearing stabilized 
in the mid-1970s (among women born in the late 1940s and during the 1950s), the distribution and mode of completed childbearing have changed very little. Cohorts born between 1950 and 1970 have nearly identical distributions in completed childbearing at age 41. Also noteworthy is that childlessness among women born around 1970 is lower (at 16 percent) than it was among the low-fertility cohorts (born in 1910). But higher than they were during the peak of the baby boom (10 percent). However, the timing of these births changed from 1940 to 2015, as shown in the age-specific birth-rate plots in Figure 11. After falling from baby boom highs 1960-1975, birth rates among women in their twenties have stabilized. Similarly, birth rates among teens have declined fairly steadily since the 1960 s, while birth rates for women in their thirties and early forties have risen steadily with delayed childbearing among recent cohorts.

\section{G. Changes in Marriage, Family Structure, and Women's Economic Outcomes}

These shifts in childbearing since 1960 have occurred at the same time as important changes in marriage, family structure, and women's economic outcomes. Shifts in family structure and marriage have been large enough that some refer to this period as the "Second Demographic Transition" (SDT), defined by declining family size, an increase in age at first marriage and age at first birth, and an outsized growth in cohabitation, premarital sex, and non-marital childbearing (Lesthaeghe and van de Kaa 1986, Lesthaeghe and Neidert 2006). Shifts in women's economic outcomes have been large enough that some have called them the "Grand Gender Convergence" (Goldin 2014) and "Rise of Women" (DiPrete and Buchmann 2013). We discuss these trends before describing the literature seeking to draw causal links between these time series.

The disassociation of childbearing and marriage has been one of the largest changes since 1960. In 1970, only 11 percent of American children were born to unmarried parents; by 2009, the figure had risen to 41 percent (Martinez, Daniels, and Chandra 2012). In the last fifty years, the share of children living with unmarried parents has risen from just over 5 percent to over 20 percent (Ellwood and Jencks 2004), with a considerably higher fraction of children expected to experience parental cohabitation at some point in their 
childhood (Graefe and Lichter 1999). These changes signal important shifts in the relationships between children, parents, and other adult relatives like grandparents (Selzer and Bianchi 2013).

Figure 12 shows that, although the share of women marrying by age 35 has fallen, the share of women forming unions, through marriage or cohabitation, by the age of 35 is the same as it was 50 years ago. The share forming a first union by age 35 is roughly as high as at any other time in the past 100 years, and the average age of women forming a first union is the same today, at just over age 22 , as it was before the baby boom (Bailey, Guldi, and Hershbein 2014). However, although the age at first union has changed very little, women tend to marry legally about 3.7 years later than they did around 1960 (birth cohorts around 1940; for men, this number is 2.7 years).

Another important change relates to who marries. Marriage is increasingly becoming an institution of the educated. More-educated women are more likely to marry by age 45 than less-educated women and, conditional upon marriage, the more-educated women divorce at substantially lower rates. Marriage rates also have diverged sharply by race since the 1960 s, with non-whites substantially less likely to ever be married (Stevenson and Wolfers 2006, McLanahan and Watson 2011). Trends in age at first marriage have also diverged, with the most educated women now marrying much later than the least educated (Bailey, Guldi, and Hershbein 2014). This pattern may be, at least in part, related to increases in women's education and occupational investments, which lead them to delay family formation.

A third distinctive feature of the last 50 years is the shift in the relationship between women's education and childbearing. Women with high and low levels of education are more similar today than in the early twentieth century in terms completed childbearing, childlessness, and the likelihood of marriage. Other trends by education diverged after 1960, with more educated women more likely to delay household formation, motherhood, and childbearing within marriage than the less educated (Bailey, Guldi, and Hershbein 2014).

These shifts in motherhood and marriage may have contributed to changes in women's opportunities in the economy, their educational attainment, and their wages and salaries. Moreover, changes in women's educational and economic opportunities may have affected the demand for contraceptives. This 
interrelatedness is a key challenge for researchers attempting to estimate the causal effects of changes in access to or the use of contraceptive technology.

\section{Research Quantifying the Effects of Contraceptive Technology on Fertility, STIs, and Socioeconomic Outcomes}

In Westoff's (1975) Presidential Address to the Population Association of America, he argued that the effect of the Pill was so large that "the entire [emphasis added] decline in births within marriage across the decade of the 'sixties' can be attributed to the improvement in the control of fertility." 16 An obvious counterargument is that the post-1960 fertility decline appears more like a reversion to trends before the baby boom - a decline typically attributed to the demand-side factors (as outlined in the previous sections). Becker's Treatise on the Family (1991: 143) states plainly that “the 'contraceptive revolution' ... ushered in by the Pill has probably not been a major cause of the sharp drop in fertility in recent decades."

That these two influential figures could disagree so completely about the impact of contraceptive technology highlights the difficulty of determining its impacts across the wide range of social outcomes that it could have affected. Discerning cause and effect from time-series evidence is complicated by the multitude of competing factors that could reasonably explain evolving outcomes. Moreover, that multiple events or trends happen concurrently does not demonstrate which caused which, whether some common factor caused both, or whether multiple unrelated factors caused each in a manner that led to a spurious relationship.

The inadequacy of aggregated time-series evidence and the rarity of randomized control trials (RCTs) have led researchers to use policy changes to construct estimates of the effects of contraceptive technology on childbearing and many other outcomes. Under the assumptions that a policy change is (a) relevant (it affected use of the technology), (b) excludable (it did not directly affect the outcome except through its impact on the use of the technology), and (c) valid (it is uncorrelated with other determinants of

\footnotetext{
${ }^{16}$ Economists have also noted the potential importance of changes in fertility control (Easterlin 1975, Michael and Willis 1976, Easterlin, Pollack, and Wachter 1980, Easterlin and Crimmins 1985, Hotz and Miller 1988).
} 
the outcome of interest), it can be used as an instrument or "natural experiment" to recover the causal effects of the use of the technology.

\section{A. Conceptual Framework for Understanding the Effects of Changes in Contraceptive Technology and Access to It}

The effects of expanding access to contraceptive technology are often ambiguous, even when expanding access does increase use. To explain this ambiguity, consider categorizing methods by the timing of their use: prior to a sexual encounter (e.g., birth control pills, injections, LARCs), during a sexual encounter (e.g., withdrawal, condoms, and diaphragms), and following a sexual encounter (e.g., emergency contraception or abortion). Although all of these methods are effective at reducing pregnancies, the effect of expanding use of and/or access to any specific method will depend on the degree to which it is used correctly, its effect on the use of other methods within the same category, its effect on the use of contraceptives in other categories, and its effect on sexual activity. For example, the effect of a policy expanding access to condoms on pregnancy will depend on the number of new users and the degree to which they use condoms correctly; how condom use affects the use of other methods prior to, during, and after a sexual encounter; and how condom use affects sexual activity. If access to condoms among teens, for instance, increases sexual behavior then expanding access to condoms could, counterintuitively, increase pregnancies (Buckles and Hungerman 2016). Peer effects in any of these behaviors could also alter pregnancy risks among individuals not directly affected by the policy. Arcidiacono, Khaja, and Ouyang (2012) also highlight that habit persistence in sexual activity could cause the short-run effects of access to contraceptives to differ from the long-run effects. Consequently, theoretical predictions about how much-or even in which direction - expansions to contraceptive access or abortion will affect outcomes are limited. Empirical research on this topic is, therefore, critical.

\section{B. The Effects of Laws and Subsidies for the Pill and other Reliable Contraceptives}

Recent research uses three main approaches to estimating the effects of the birth control pill on population-level outcomes in the 1960s and 1970s. The first relies on changes in the effectiveness of state- 
level restrictions on the sale of the contraceptives before and after the Griswold v. Connecticut. When the Pill was introduced, anti-obscenity statutes (Comstock laws) varied significantly in their language regarding the sale of contraceptives. Bailey (2010) shows that legal restrictions in 24 states affected the diffusion of oral contraception and reduced the speed of fertility declines in restrictive states from 1958 to 1965 . After the Griswold decision lifted these restrictions, however, fertility rates in formerly restrictive states dropped sharply relative to those without restrictions. That is, increasing legal access to contraception decreased fertility rates. There is little reason to expect the demand for children to change with this pattern, but it is clear that the supply of contraceptives did-especially those that were medically prescribed and tightly regulated. Counterfactual estimates imply that, without sales bans, the marital fertility rate could have been 8 percent lower in states that had sales bans and 4 percent lower in the U.S. as a whole. Bailey (2010) suggests that as much as 40 percent of the decline in the marital fertility rates from 1955 to 1965 might be attributable to the Pill.

The second research strategy uses the early, county-level expansion of federally funded family planning programs to quantify the effects of subsidized contraception on the childbearing of lower-income women. In theory, these subsidies could have influenced the use of any type of contraceptive. Because other types of contraception were not expensive and did not require doctors' visits, the vast majority of funds increased access to the most expensive and most reliable method of the day: the Pill.

Beginning with the 1964 Economic Opportunity Act and continuing with the passage of Title X, over 650 family planning programs began or expanded from 1964 to 1973 . Bailey (2012) uses the idiosyncratic timing of the granting process at the county level to estimate the program's effects on fertility rates using models that also account for the availability of abortion. The results show that family planning programs, which reduced the cost of contraceptives and increased the availability of related services, led to substantial and sustained declines in fertility rates. Although these programs generally increased contraceptive use, they had the largest effects on popular and expensive technologies like the Pill. The general fertility rate fell by roughly 2 percent within 5 years of establishing federal family planning programs and remained almost as low up to 15 years from establishment. Because family planning 
programs served mostly lower-income women and operated in only one-fifth of all counties during this period, these programs accounted for a small portion of the overall decline in fertility rates over the 1960s. Assuming these programs were used only by low-income women implies a reduction in fertility rates among treated women of 20 to 30 percent within a decade - magnitudes large enough to account for half of the 1965 gap in childbearing between poor and non-poor women. Follow-up work by Bailey, Malkova, and McLaren (2016) shows that children born after these family planning programs began were significantly less likely to grow up in poverty or reside in households collecting public assistance. In summary, family planning programs reduced birth rates among poor women and increased economic resources available to children.

A third approach exploits state-level restrictions on contraceptive access for unmarried, younger women. Even as older, married women gained legal access to the Pill, younger, unmarried women were limited by a number of state laws. Using variations of these laws across states, studies show that legal access to the Pill affected marital and birth timing and had broad effects on women's and men's education, career investments, and lifetime wage earnings (Goldin and Katz 2002, Bailey 2006, Guldi 2008, Hock 2008, Bailey 2009, Bailey et al. 2011, Guldi 2011). Affected women and men were more likely to enroll in and complete college. Women were more likely to work for pay, invest in on-the-job training, and pursue nontraditional professional occupations. And as women aged, these investments paid off. Thirty percent of the convergence of the gender wage gap in the 1990s can be attributed to these changing investments made possible by the Pill (Bailey, Hershbein, and Miller 2012). Using a slight modification to this empirical strategy, Ananat and Hungerman (2012) show that women's access to contraception at younger ages improved the economic resources of their children.

Because changes in abortion legalization and the Pill access laws are often collinear, Myers (2012) argues that legalized abortion may explain a portion of the effects attributed to the Pill. However, Bailey, Guldi, and Hershbein (2013) show that Myers' estimates are not statistically distinguishable from Bailey's revised estimates (Bailey 2009, Bailey, Hershbein, and Miller 2012). In addition, Bailey (2009) shows that 
the effects of state-level restrictions on age at access appear even stronger when examining women too young to have been affected by legalized abortion.

Each of the preceding sets of studies examine how the introduction of highly reliable, modern, female-controlled contraception affected childbearing outcomes. This does not necessarily imply that expanding access to lower-income populations will have similar effects. Interestingly, however, the results of studies based in the 1960s and 1970s are consistent results with recent work using state-level variation in Medicaid eligibility for family planning services for the near poor. Kearney and Levine (2009) show that increased eligibility reduced birth rates for teens and older women, and these effects appear to be driven by increased use of reliable contraceptives. It is also consistent with evidence that recent funding cuts to family planning have increased birth rates (Lu and Slusky 2016, Packham 2016).

\section{The Effects of Abortion}

Closely related to studies focusing contraception, research quantifying the effects of legal abortion leverages the staggered timing of abortion legalization across states. Levine et al. (1996) show that the early legalization of abortion in five states around 1970 led to a 5-percent reduction in the birth rate in these states relative to the decline in the rest of the U.S. The effects were especially large for teens, women over age 35, and nonwhites, and evidence also indicates spillover effects onto nearby states (Angrist and Evans 1999, Levine et al. 1999). Joyce, Tan, and Zhang (2013), who analyzed abortions in New York by state of residence in the era before Roe v. Wade, found that being 100 miles farther from the nearest abortion provider decreased state-level abortion rates by around 12 percent and increased birth rates by 2 to 3 percent. Gruber, Levine, and Staiger (1999), Ananat, Gruber, and Levine (2007), and Ananat et al. (2009) show that legalized abortion led to decreases in completed childbearing - largely due to increases in childlessnessand improvements in the material living circumstances of children.

In contrast to estimates using variation in the 1960s and early 1970s, subsequent restrictions on abortion, like parental involvement or mandatory waiting periods, have been found to have minimal effects on fertility rates, with some evidence showing a slight reduction in abortion rates (and increased 
contraceptive use) among teens (Bitler and Zavodny 2001, Levine 2003). Similarly, analyses of limitations on the use of Medicaid funding for abortion found it did not appreciably affect birth rates, it lowered abortion rates only slightly as many women traveled to nearby states for abortions (Blank, George, and London 1996), and it lowered pregnancy rates among teens (Kane and Staiger 1996).

\section{The Effects of LARCs}

Researchers have begun to document the effects of expanding access to the "new generation of LARCs" by examining a variety of interventions, focusing primarily on the St. Louis Contraceptive Choice Project (CHOICE) and the Colorado Family Planning Initiative (CFPI).

\section{$\underline{\text { St. Louis Contraceptive Choice Project (CHOICE) }}$}

A significant share of research on the effects of LARCs has focused on the CHOICE project, an intervention conducted from 2007 to 2011 to promote the use of LARCs by removing financial and knowledge barriers among women in St. Louis, Missouri. The researchers who implemented and evaluated the intervention have reported their findings in more than 60 published papers and these studies have been cited heavily by policymakers and advocates (Broughton et al. 2016).

The CHOICE project is widely viewed as a success because 75 percent of study participants chose to use a LARC when offered their choice of contraceptive - a huge share given estimates that less than 5 percent of women at participating clinics were using a LARC method prior to the intervention (McNicholas et al. 2014). These statistics are often cited as evidence for potential to greatly expand LARC use. Moreover, statistics demonstrating relatively low abortion rates among all participants and relatively low birth rates among teen participants is often cited as evidence that the program reduced unintended pregnancy.

However, several factors suggest caution when interpreting these results. First, to be recruited for the study, women had to be interested in beginning to use a new form of contraception (i.e., initiating contraceptive use or switching their primary contraceptive). Women wishing to continue their methods were not included in the study, which contributes heavily to the LARC take up rate of 75 percent. Second, enrollment was a 1.5 to 2 hour process for which individuals received their chosen contraceptive at no cost, 
in addition to a $\$ 15$ gift card as compensation for their time. Third, participants were recruited "at specific clinic locations and via general awareness about CHOICE through their medical providers, newspaper reports, study flyers, and word of mouth" (Secura et al. 2010). Some participants had just had an abortion. Consequently, study participants may be particularly selected on wanting to avoid pregnancy and on wanting to use relatively expensive contraceptives, such as LARCs, relative to the population at large. ${ }^{17}$ Indeed, Karpilow and Thomas (2016) highlight that estimated effects will be biased toward finding reductions in pregnancy (and associated outcomes) in any such study that compares a program's participants to a broader set of women (Peipert et al. 2012), simply because the participants are a selected set of women who intend to begin using a contraceptive whereas broader populations will include many sexually active women without this intent.

This selection is inevitable, but causal inferences about the program could still be drawn had the treatment been randomized within women selecting into the study. Given the lack of randomization, it is difficult to extract any insights into the causal effects of the program from published statistics on the sexual behaviors, STI rates, pregnancy rates, and abortion rates.

\section{Colorado Family Planning Initiative (CFPI)}

The CFPI, which made it possible for Title X clinics in Colorado to provide LARCs at no cost beginning in 2009, is another large-scale intervention. The CFPI was implemented by the Colorado Department of Public Health and Environment. Following Governor Hickenlooper's claim that the CFPI was responsible for a 40 percent decline in teen birth rates from 2009 to 2013, CFPI has received significant media attention. ${ }^{18}$

\footnotetext{
${ }^{17}$ Indeed, it appears as if the individuals who participated in the program may have been more and more "selected" in this respect over time: 67 percent of the first 2500 participants selected a LARC (Secura et al. 2010) whereas this number increased to 71 percent in an evaluation of the first 5086 participants (Mestad et al. 2011) and increased further to 75 percent for the full set of 9256 participants (McNicholas et al. 2014).

18 This includes a front-page article in the New York Times on July 5, 2015 calling the program a "startling success." (Tavernise 2015)
} 
Although more analyses need to be done, CFPI appears to have had a large impact on LARC use. The first study on the initiative, written by staff members of the Colorado Department of Public Health and Environment and a coauthor, reported that LARC use among females aged 15-24 visiting Colorado's Title X clinics increased from less than 5 percent to 19 percent by 2011 (Ricketts, Klingler, and Schwalberg 2014). Lindo and Packham (forthcoming) show a tenfold increase (from 2.6 percent to 25.0 percent) in the share of teens visiting Title X clinics in Colorado who were using a LARC as their primary form of contraception between 2008 and 2014. This shift in LARC use contrasts sharply with the trend for teens visiting Title $\mathrm{X}$ clinics in other states, which saw more modest growth over the same time period - from 1.9 percent to 7.4 percent.

Given its sizeable impact on LARC usage among young women visiting Title $\mathrm{X}$ clinics, it is reasonable to think that the CFPI likely had impacts on pregnancy and on other outcomes. ${ }^{19}$ Lindo and Packham (forthcoming) compare changes in outcomes in Colorado counties with Title $\mathrm{X}$ clinics to the changes observed in other U.S. counties with Title X clinics. They examine the sensitivity of the estimates to a wide set of potential confounders, including differential trends in the treated counties, and conduct a number of diagnostic tests that help to establish the validity of their difference-in-differences research design. Their estimates indicate that the CFPI reduced the teen birth rate in Colorado counties with Title X clinics by 6.4 percent over five years, with larger effects in the second through fifth years following implementation and in relatively high-poverty counties. They estimate that the additional 6,000 or so LARCs provided to teenagers through the initiative prevented approximately 1,500 teenage births through 2014.

\footnotetext{
${ }^{19}$ Ricketts, Klingler, and Schwalberg (2014) provided first evaluation of the effects of the program in an analysis of birth rates, abortion, and the number of infants enrolled in the Special Supplemental Nutrition Program for Women, Infants, and Children. Although the researchers did not provide evidence regarding the validity their comparison group (Colorado counties without Title X clinics), their analyses suggest large benefits of the initiative in Colorado counties with Title X clinics. Goldthwaite et al. (2015) use the same approach to study infant health outcomes.
} 


\section{Other Interventions}

Two randomized control trials provide additional evidence on the potential for LARC access to reduce unintended pregnancy. Harper et al. (2015) presents the results of a cluster-randomized trial, conducted at selected Planned Parenthood Federation of America clinics, in which treated clinics received training on LARC counselling and insertion (Harper et al. 2015). Participants for the study were recruited when they presented at a health center for family planning or abortion care visits if they were aged 18-25 years, sexually active within the previous three months, not pregnant, and not wanting to be pregnant within the next twelve months. Participating women at the treated centers were significantly more likely to select a LARC during their visit. Although the published study is titled "Reductions in pregnancy rates in the USA with long-acting reversible contraception," the scale of the study was such that the intervention did not find a significant effect on pregnancy in the one-year follow-up. The estimated effect on pregnancy rates for those attending family planning clinics, however, was statistically significant.

The Teen Options to Prevent Pregnancy program is the other randomized control trial that provides some suggestive evidence that expanding LARC use can reduce unintended pregnancies among young women. Rotz et al. (2016) reports that this intervention, which aimed at reducing rapid repeat pregnancies among low-income teen mothers in Columbus, Ohio, significantly increased LARC use and reduced the number of participants reporting a pregnancy within 18 months. However, the authors cannot identify which components of the program are responsible for these encouraging results, as treated women were provided with telephone-based care coordination, facilitated access to contraceptive services, access to a social worker, and the program was "delivered using motivational interviewing techniques designed to help participants identify and realize their personal goals for contraceptive use and birth spacing."

\section{E. The Effects of Emergency Contraception}

Emergency Contraception is still rather new, and very little research has quantified its effect. Raymond, Trussell, and Polis (2007) review the results from the ten randomized control trials on emergency contraception. These studies varied in their size and in their method of delivery, but all provided at least 
one package in advance of need. The studies found that treatment increased the use of emergency contraception, but none individually found significant effects on pregnancy or abortion. They also report that the subset of studies collecting information on sexually transmitted infections (STIs) find no evidence of effects.

Quasi-experimental studies are useful complements to these randomized control trials, which may have been too small to identify effects. Specifically, researchers using observational data can evaluate the effects of access to emergency contraceptives by evaluating the impacts of policy changes affecting access for a large number of individuals. State and federal policy changes allowing over-the-counter access to emergency contraceptives have been studied extensively.

Zuppann (2011) finds statistically significant effects on childbearing, but Gross, Lafortune, and Low (2014) and Mulligan (2016) report that these estimates are not robust to controlling for state-specific linear trends. Mulligan (2016) additionally finds that over-the-counter access significantly increases STIs. Durrance (2013), who exploits variation in access across Washington counties generated by agreements between physicians and pharmacists under the Emergency Contraception Collaborative Agreement Pilot Project, finds significant effects of access on gonorrhea and finds no effect on abortion or childbearing. Using the same research design, Cintina (2016) finds that access causes statistically significant but "economically moderate" reductions in abortion if access is measured by distance to the nearest pharmacy with emergency contraceptives instead of by the fraction of pharmacies participating in a given countyyear. ${ }^{20}$ Gross, Lafortune, and Low (2014) and Mulligan (2016) find little evidence of effects on abortion for women of any age using difference-in-differences strategies exploiting state and federal policy changes; Cintina and Johansen (2015) find that access significantly reduces abortion rates among women aged 18 and 19 using a difference-in-differences strategy that examines the same policies but exploits differential changes in access for women of different ages.

\footnotetext{
20 Girma and Paton (2011) also find that access to emergency birth control increases STIs using variation across localities and across time in England.
} 
To summarize, the body of work using observational data to examine policies expanding over-thecounter access to contraceptives suggests that these policies have not had significant effects on childbearing, although they likely have increased STIs and reduced abortions. These results are consistent with the idea that the reductions in childbearing realized through policies that increase access are offset by increases in unprotected sex (and perhaps reductions in abortion). Indeed, researchers have found evidence that these policies have led to increases in unprotected sex (Atkins and Bradford 2015a, b, Mulligan 2016).

\section{Next Steps in Understanding How Contraceptive Technology Has Shaped Women's Outcomes}

A significant amount of research investigates the links between contraceptive technology and women's outcomes, but a tremendous amount of work remains to be done. Even as researchers continue to make progress in this area, new examinations are needed as technology advances, preferences evolve, and accessibility and affordability change.

The large body of work focusing on the 1960s "contraceptive revolution" provides consistent evidence on several outcomes by researchers using a variety of data sources and methodologies. First, large decreases (primarily in the 1960s and 1970s) in the regulation of contraception and abortion or increases in subsidies for contraception through family planning programs reduced birth rates by allowing women to delay childbearing and, in some cases, prevent further childbearing. Policy changes in more recent years have been smaller in scope and have likely had smaller effects that are more difficult to detect. Second, the effects of greater access to family planning and abortion services vary by age, demographic group, type of policy intervention, and context. Third, these policy changes seem to have contributed to women's longerterm economic advancement. Studies of the Pill find effects on cohabitation, age at first marriage, educational attainment, occupational choice, and the gender wage gap. Fourth, large policy changes have increased the likelihood that children are born into households with greater material resources, likely leading to improved outcomes for children. Some of the improvements in the material resources of children reflect the greater earnings capacity of both men and women, and some reflect changes in the population who select into parenthood at different times. 
The recent surge in LARC use seems to be one of the most pressing areas in need of further research. By highlighting a wide range of outcomes that can be affected by changes in access to contraceptive technology, the large body of work focusing on the 1960s "contraceptive revolution" provides something of a road map for researchers investigating more recent trends. Notable is the dearth of rigorous studies documenting the effects of LARCs on childbearing; no study we can find examines LARCs' effects on education, income, marriage, or the material resources of children. The growing political challenges to funding family planning initiatives may provide ample new opportunities for these evaluations. It also prioritizes the generation of new evidence regarding the value of these interventions for the research community. 
Figure 1. Survey Responses Regarding Support for the Birth Control Movement and Family Planning Programs, 1936-2012

Percent answering "yes"

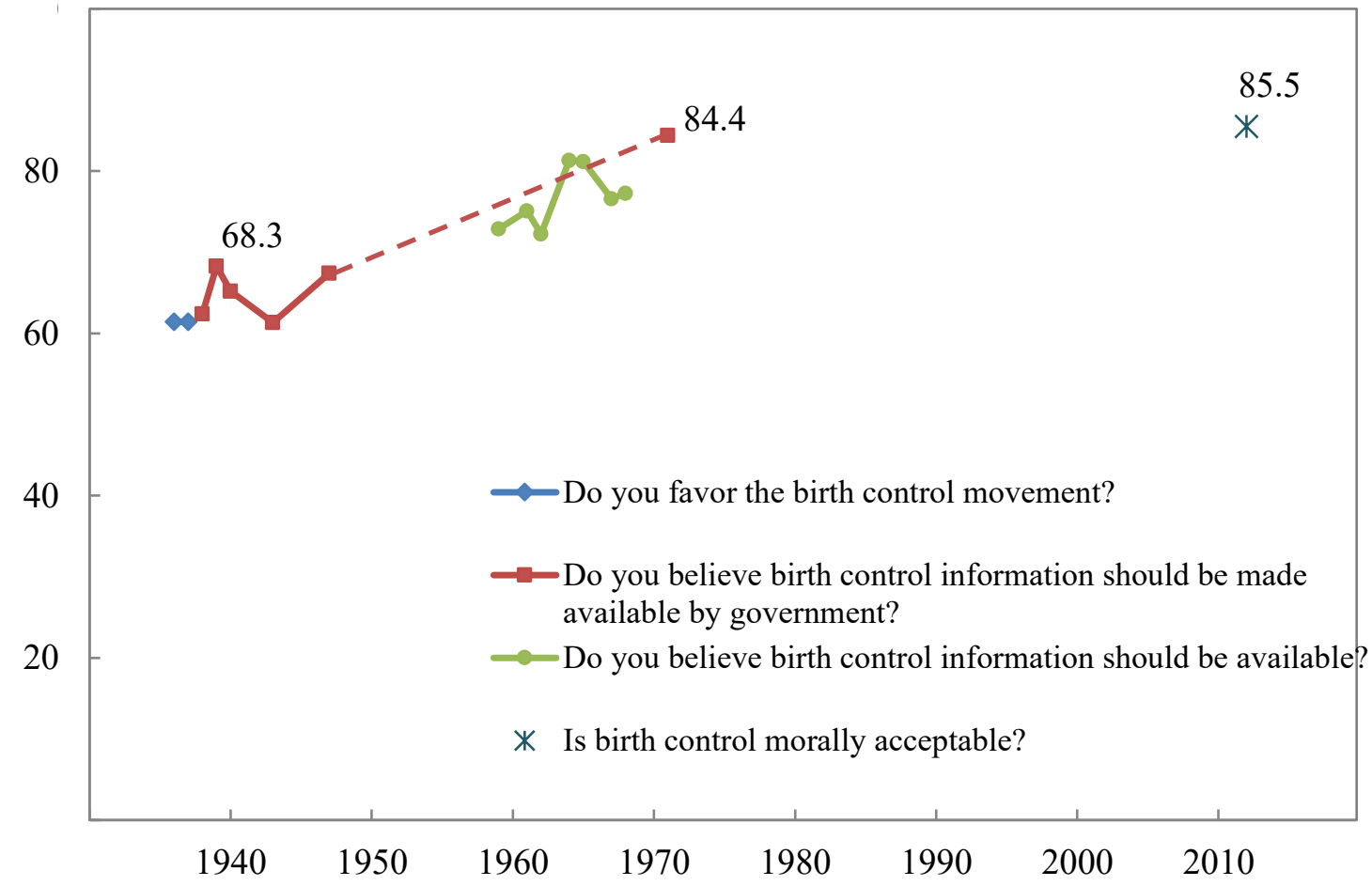

Source: Author's tabulations using Roper Center data. See the online appendix for further details on the questions and the surveys. 
Figure 2. Survey Responses Regarding Support Abortion Access, 1973-2012

Percent answering "yes"

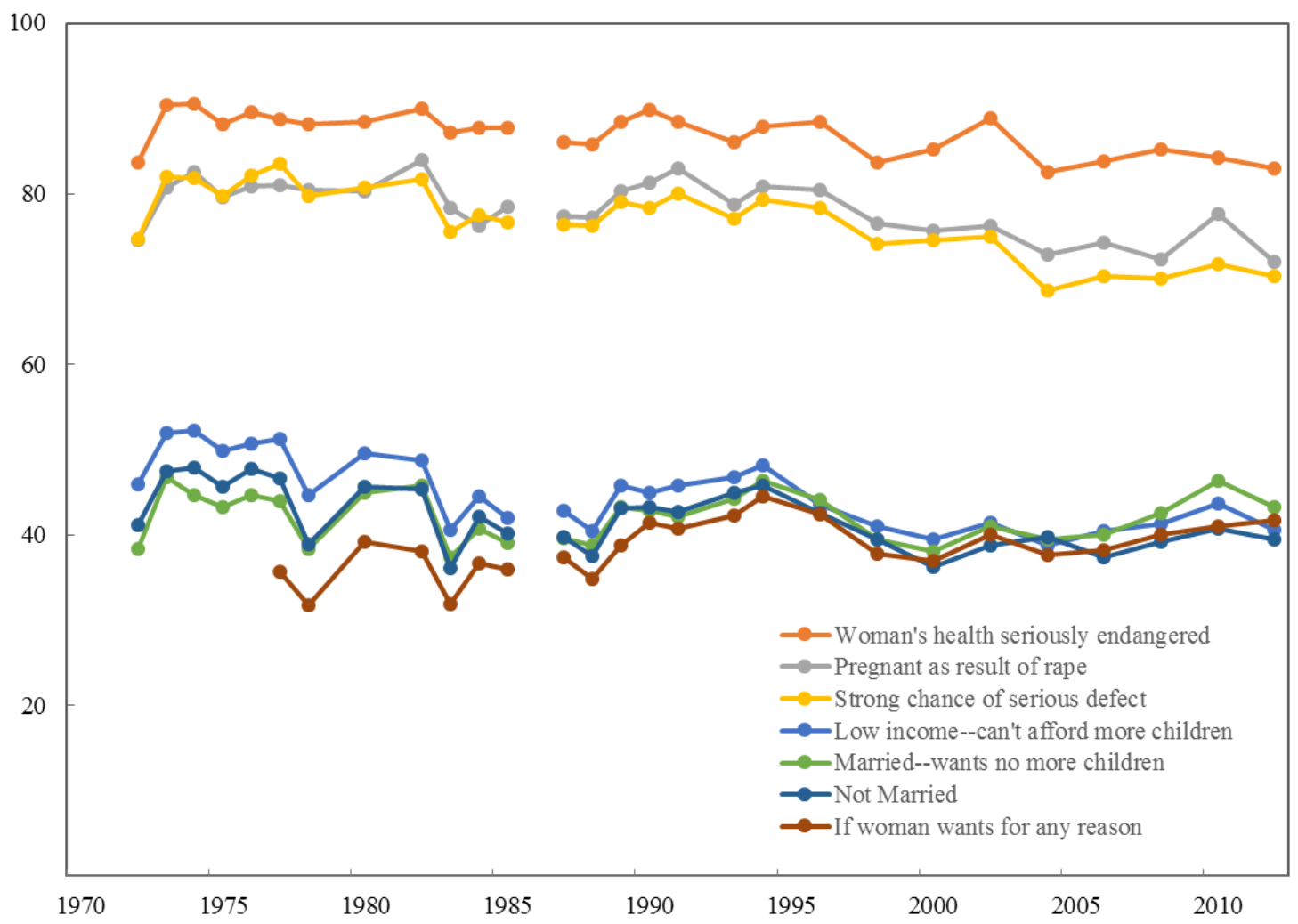

Source: General Social Survey Data from Smith and Son (2013). 
Figure 3. Percent of Women Aged 15-44 Using Contraception, by Marital Status

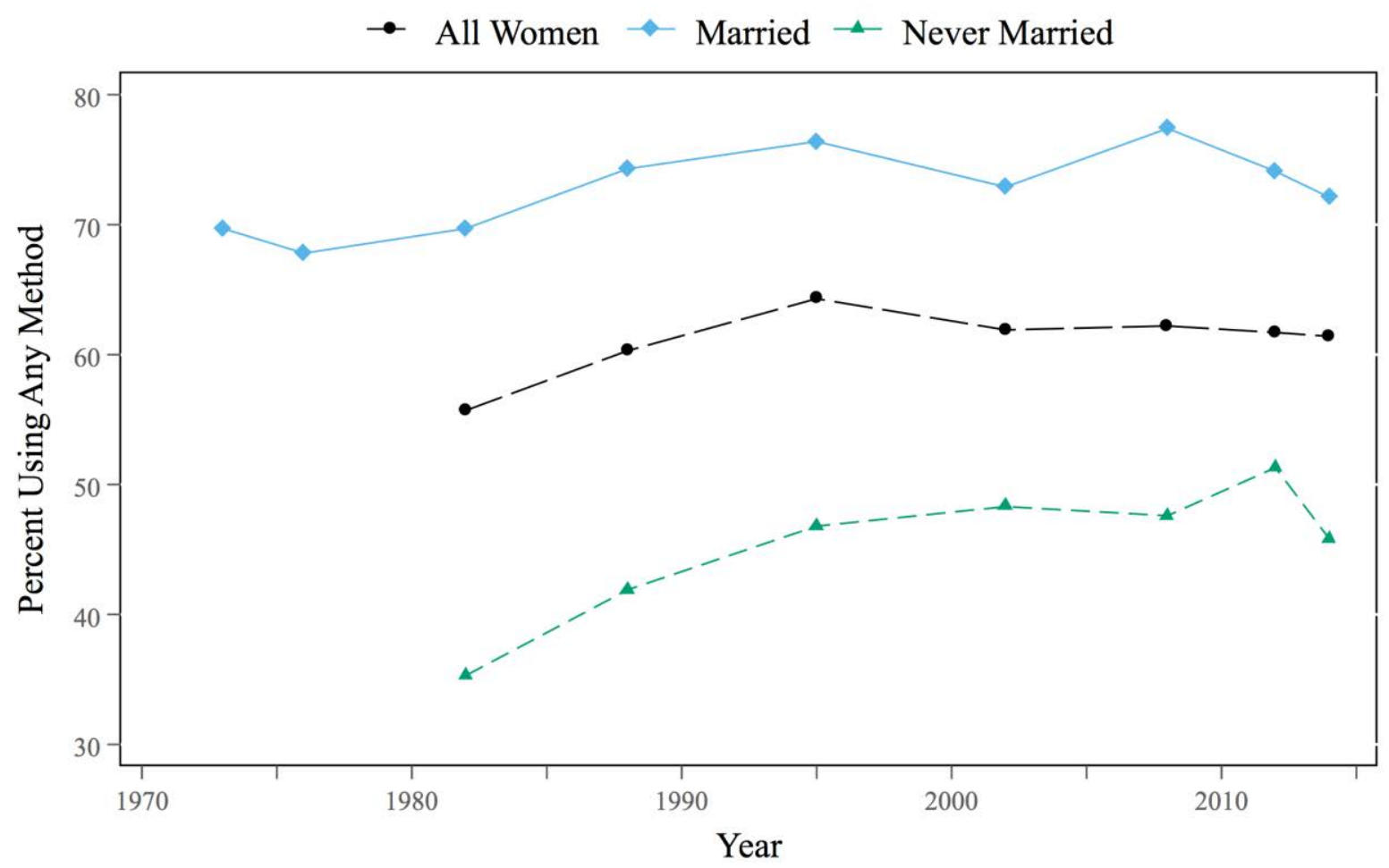

Notes: Statistics are constructed using data from the National Survey of Family Growth (NSFG). Before 1982, the NSFG only surveyed women who were married, previously married, or had children of their own in the household. 
Figure 4. Percent of Women Aged 15-44 Using Contraception, Alternative Groupings
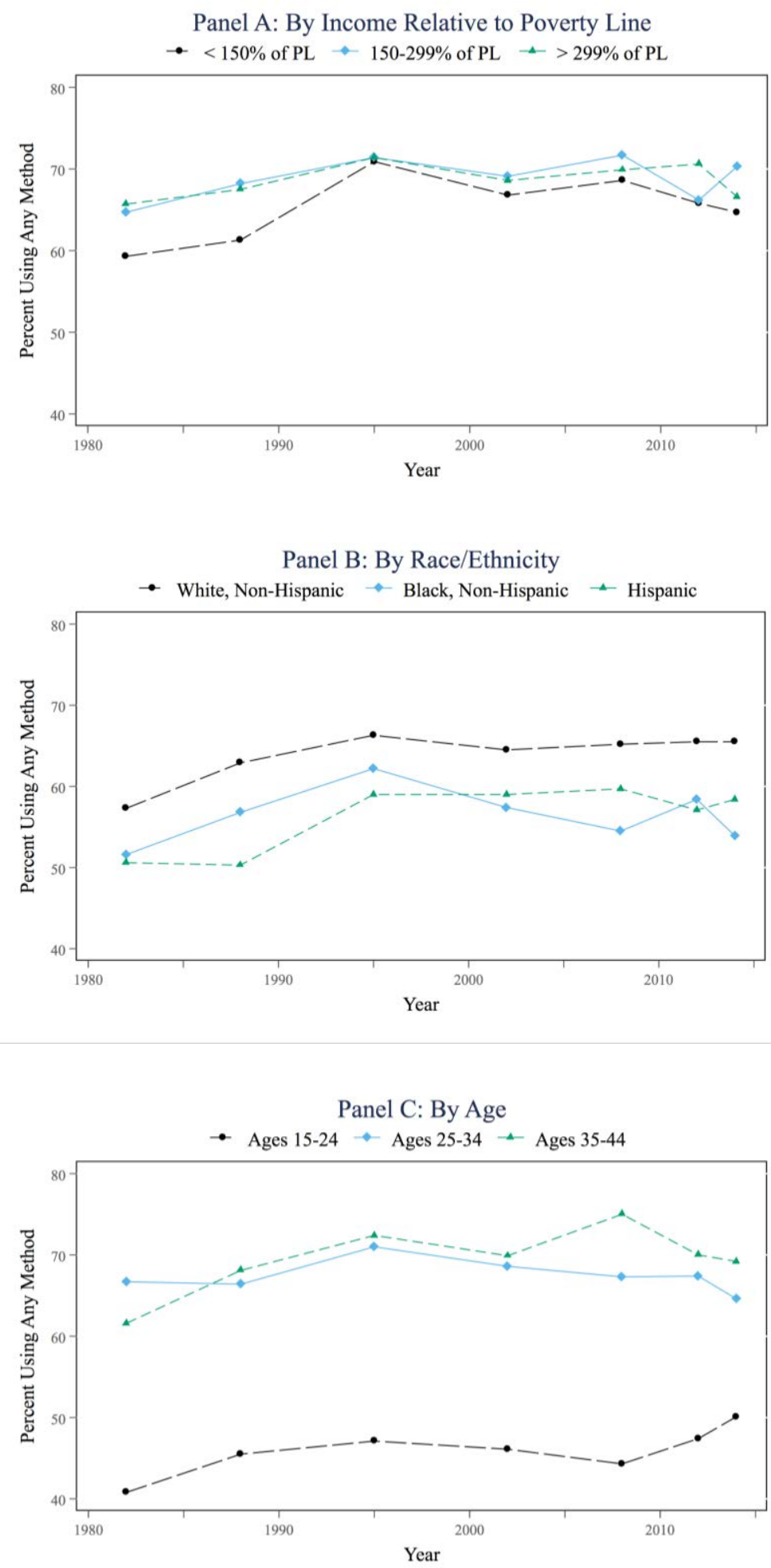

Notes: Statistics are constructed using data from the National Survey of Family Growth (NSFG). 
Figure 5. Primary Method among Women Using Some Form of Contraception
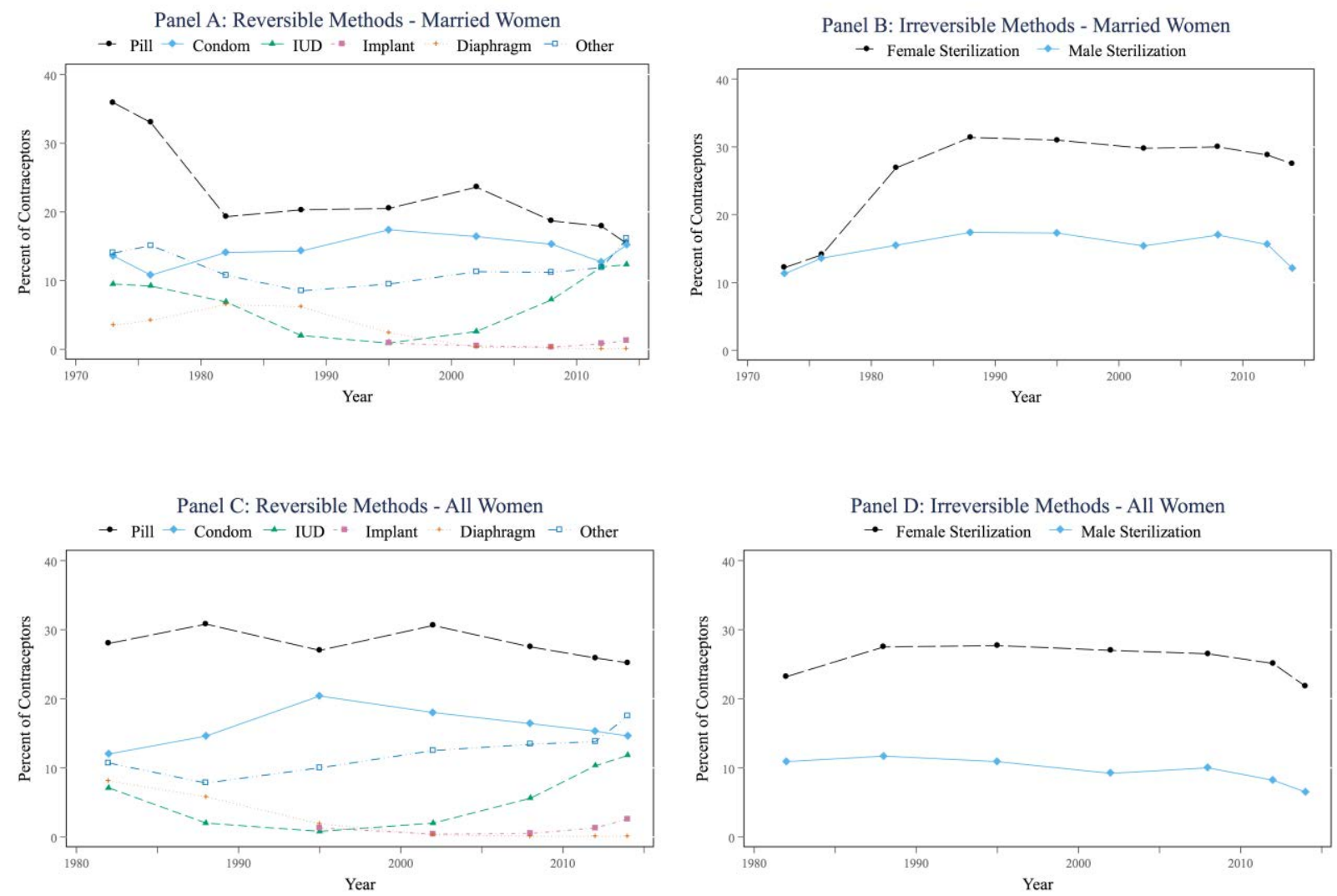

Notes: Statistics are constructed using data from the National Survey of Family Growth (NSFG). 
Figure 6. LARC Use among Women Using Some Form of Contraception, Alternative Groupings
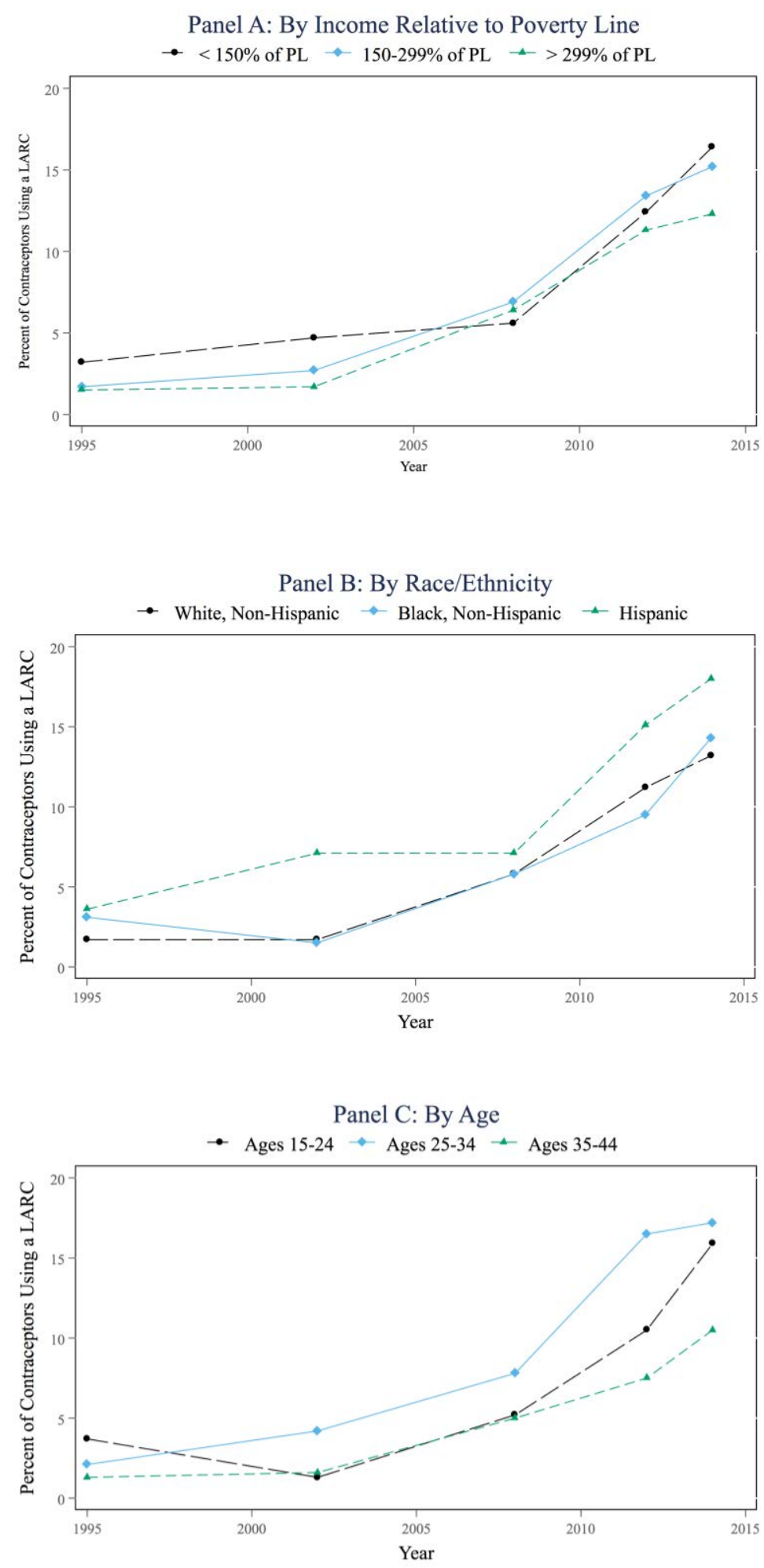

Notes: Statistics are constructed using data from the National Survey of Family Growth (NSFG). 


\section{Figure 7. Use of Emergency Contraception}
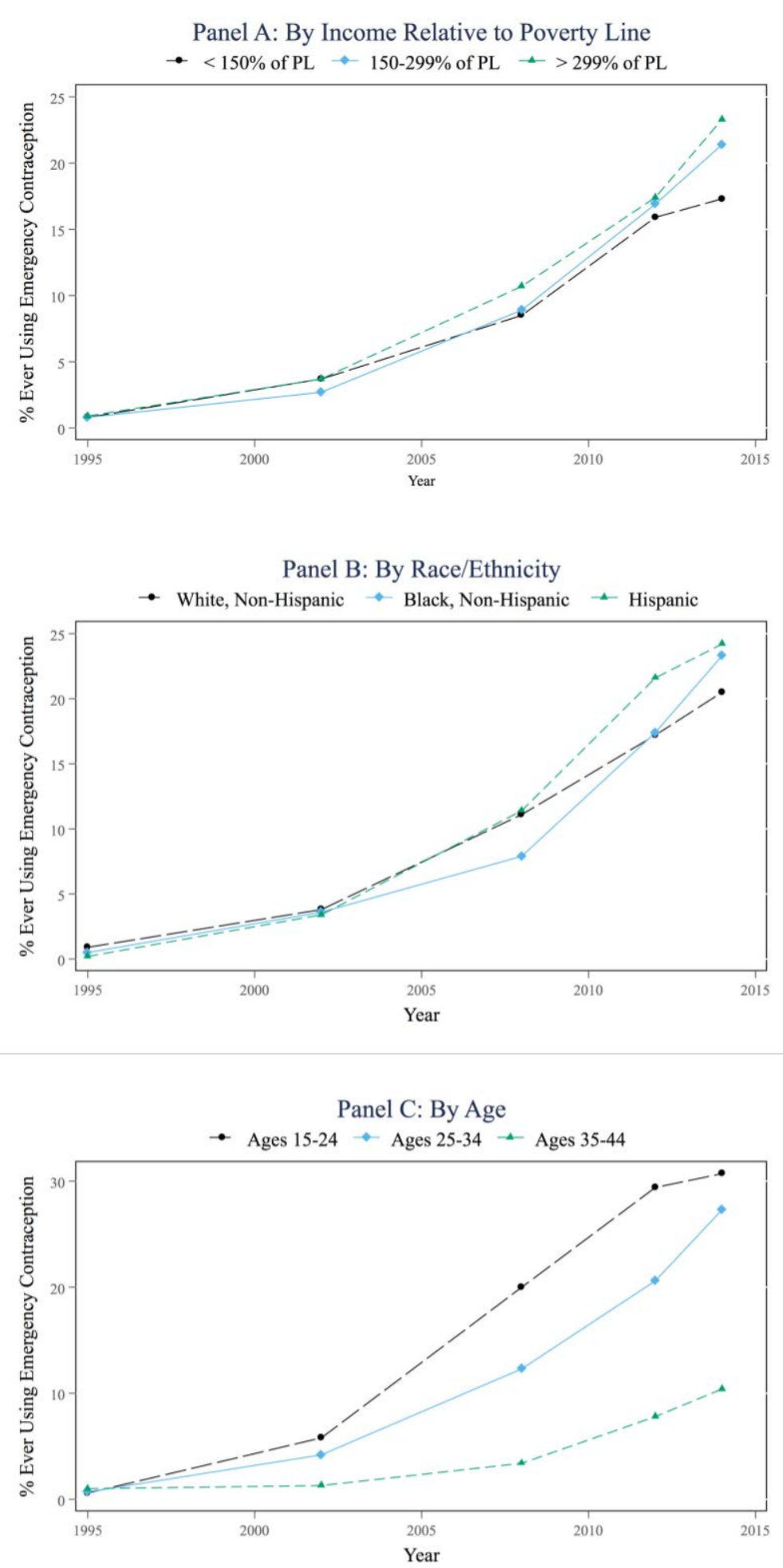

Notes: Statistics are constructed using data from the National Survey of Family Growth (NSFG). 


\section{Figure 8. Use of Abortion, 1982-2014}
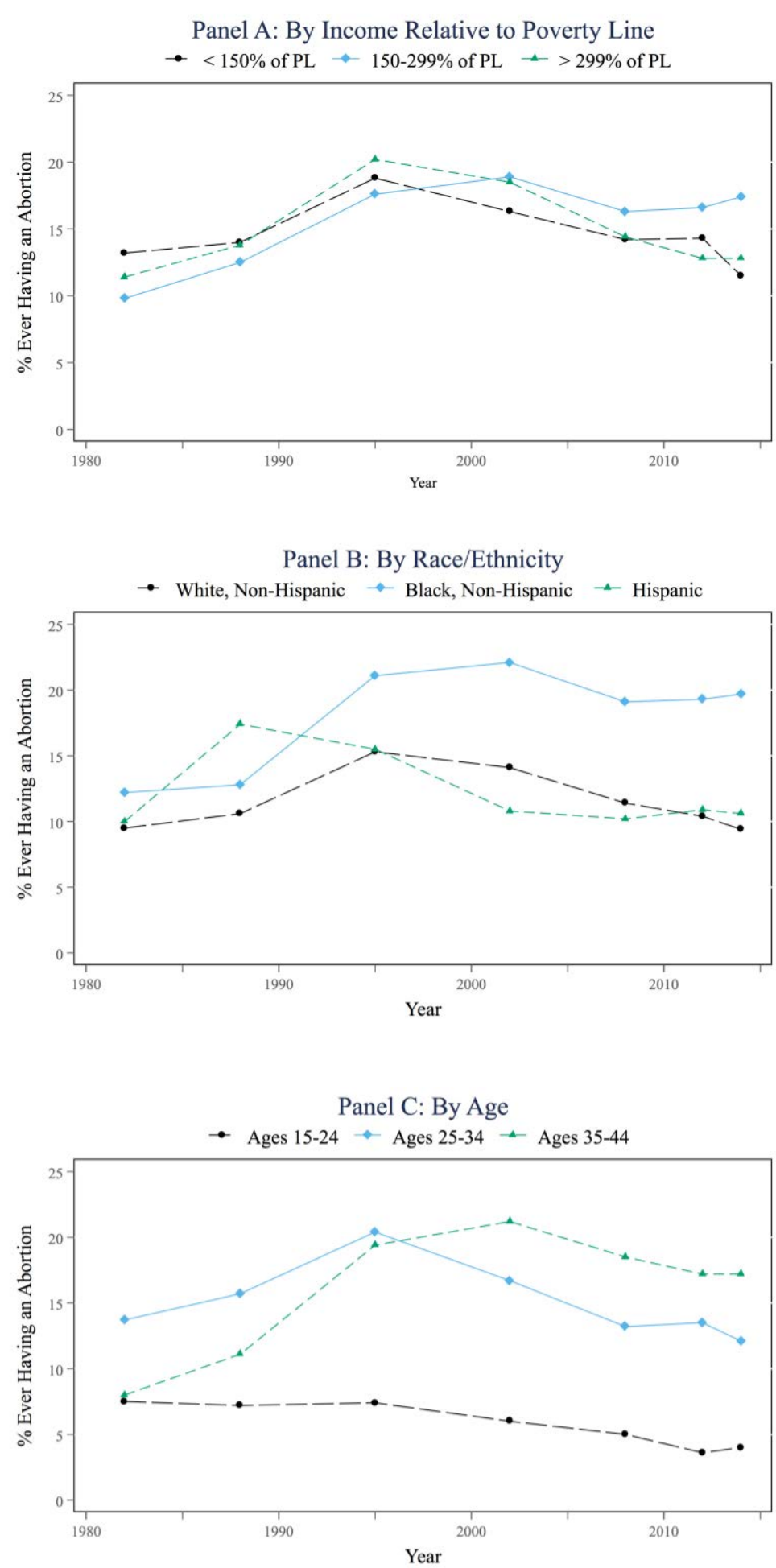

Notes: Statistics are constructed using data from the National Survey of Family Growth (NSFG). 


\section{Figure 9. General Fertility Rate and Completed Childbearing, by Year and Cohort}

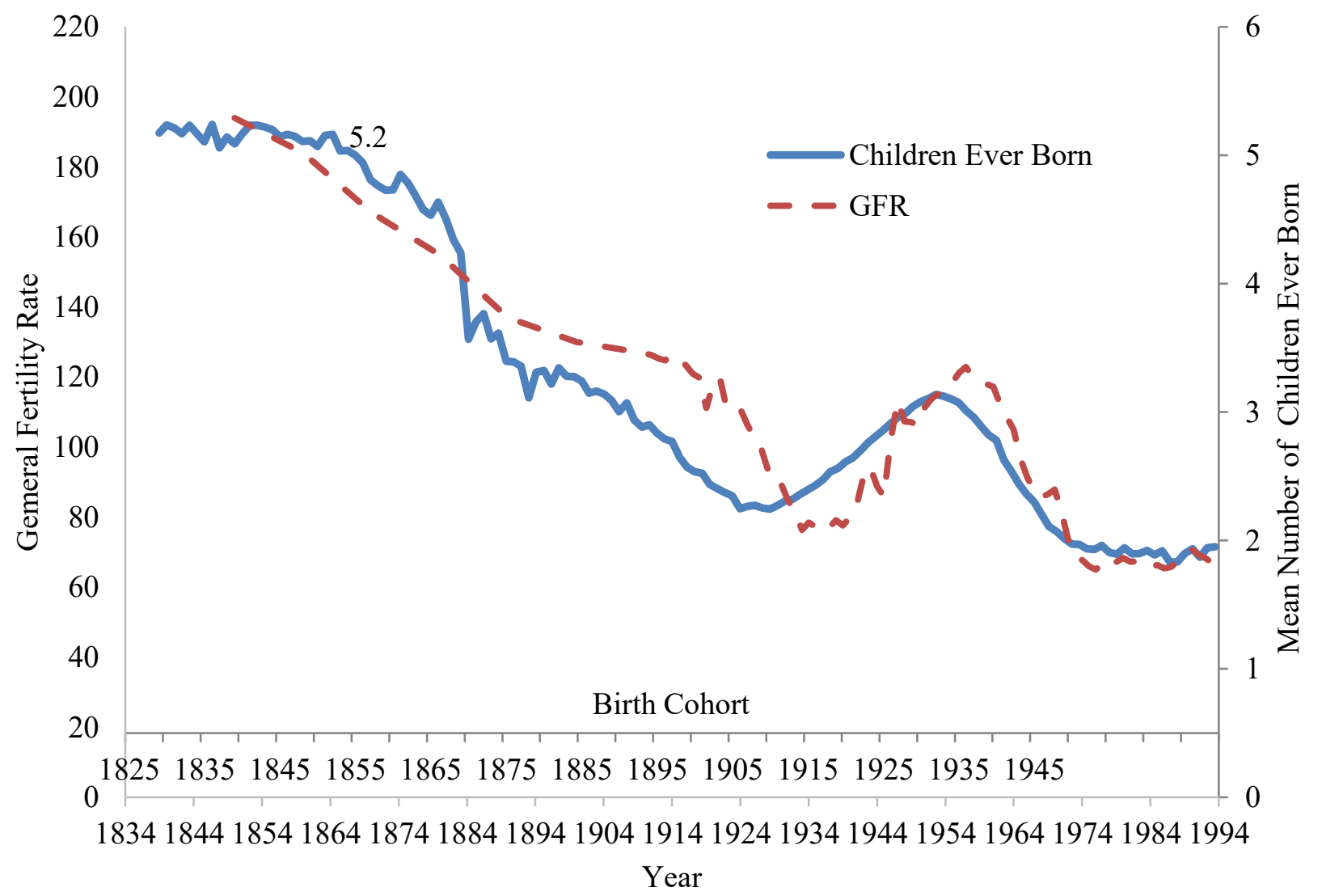

Notes: The general fertility rate (GFR) is plotted on the left vertical axis and is measured as the number of births per 1000 women ages 15 to 44 in the population (lower x-axis). Before 1910, this series is for white women only. Mean live births is plotted on the right vertical axis and is the mean self-reported number of children ever born for each birth cohort as measured between the ages of 41 and 70 . This series is plotted by birth cohort (upper $\mathrm{x}$-axis).

Sources: Fertility rates are from the National Center for Health Statistics, http://www.cdc.gov/nchs/data/statab/t001x01.pdf. Mean live births are computed using the 1900, 1910 and 1940 1990 Decennial Census IPUMS samples (Ruggles et al. 2010) and the 1995-2010 June Current Population Survey. 
Figure 10. Completed Childbearing by Parity, Birth Cohorts of 1910 to 1969

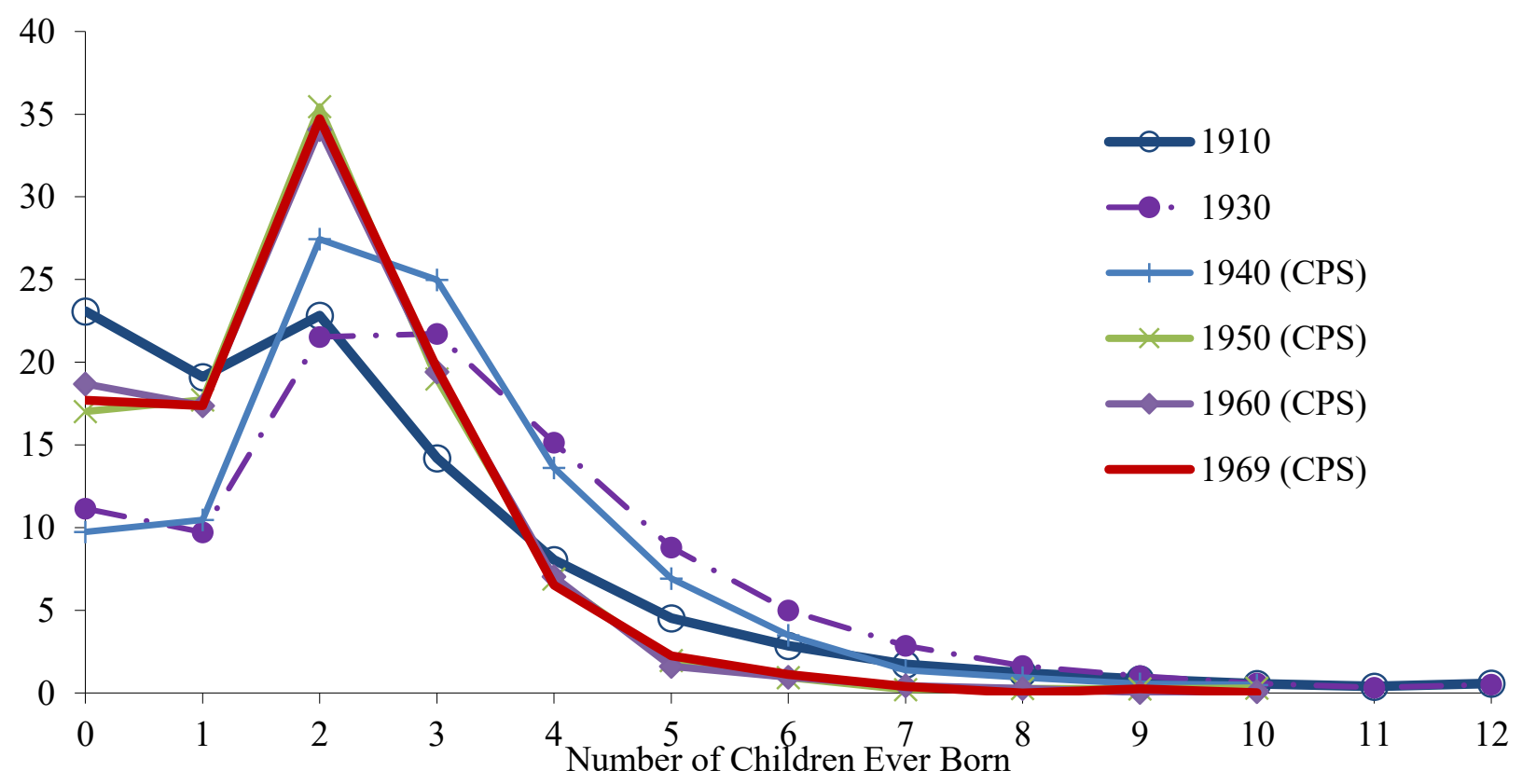

These figures plots the percent of women ages 41 to 70 who report having each number of children. We include never-married women in the 1970 to 1990 Censuses and June CPS when available so that figures include the recent rise in non-marital childbearing. Children ever born is top-coded at 12 in the Census and 10 in the CPS. Source: 1850 to 1930 cohorts use the 1900, 1910, 1940-1990 Decennial Censuses (Ruggles et al. 2010); 1940 to 1969 cohorts use the 1981 through 2010 June Current Population Survey (CPS). 
Figure 11. Age-specific Birth Rates, 1940 to 2014

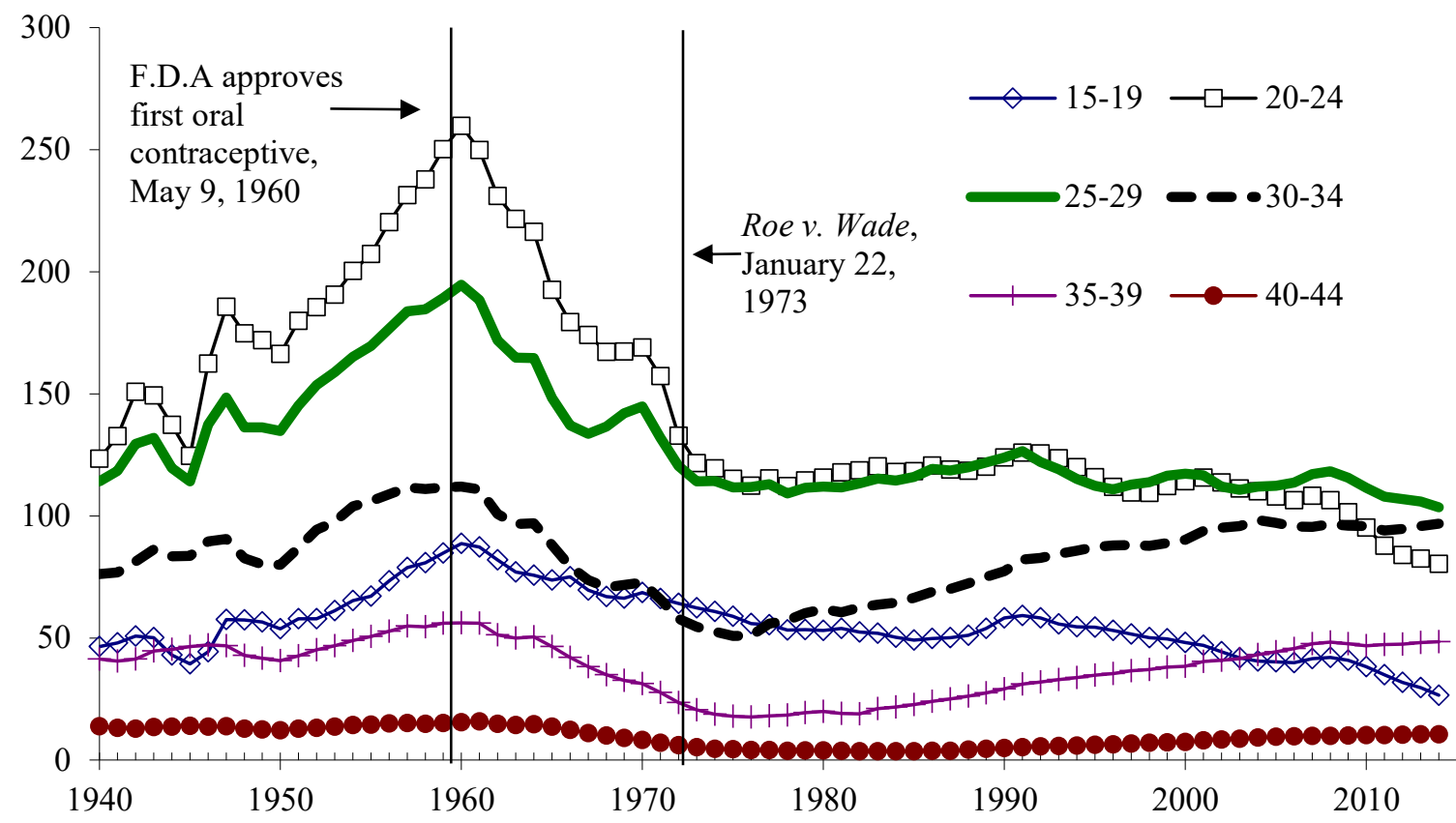

This figure plots the number of births $x 1000$ to women in a particular age group over the number of women in the particular age group. Source: Division of Vital Statistics, National Center for Health Statistics, downloaded http://www.cdc.gov/nchs/births.htm. Census figures computed from census data. 


\section{Figure 12. Mean Age at First Marriage/Cohabitation and First Birth and Share Ever Marrying, by Birth Cohort}

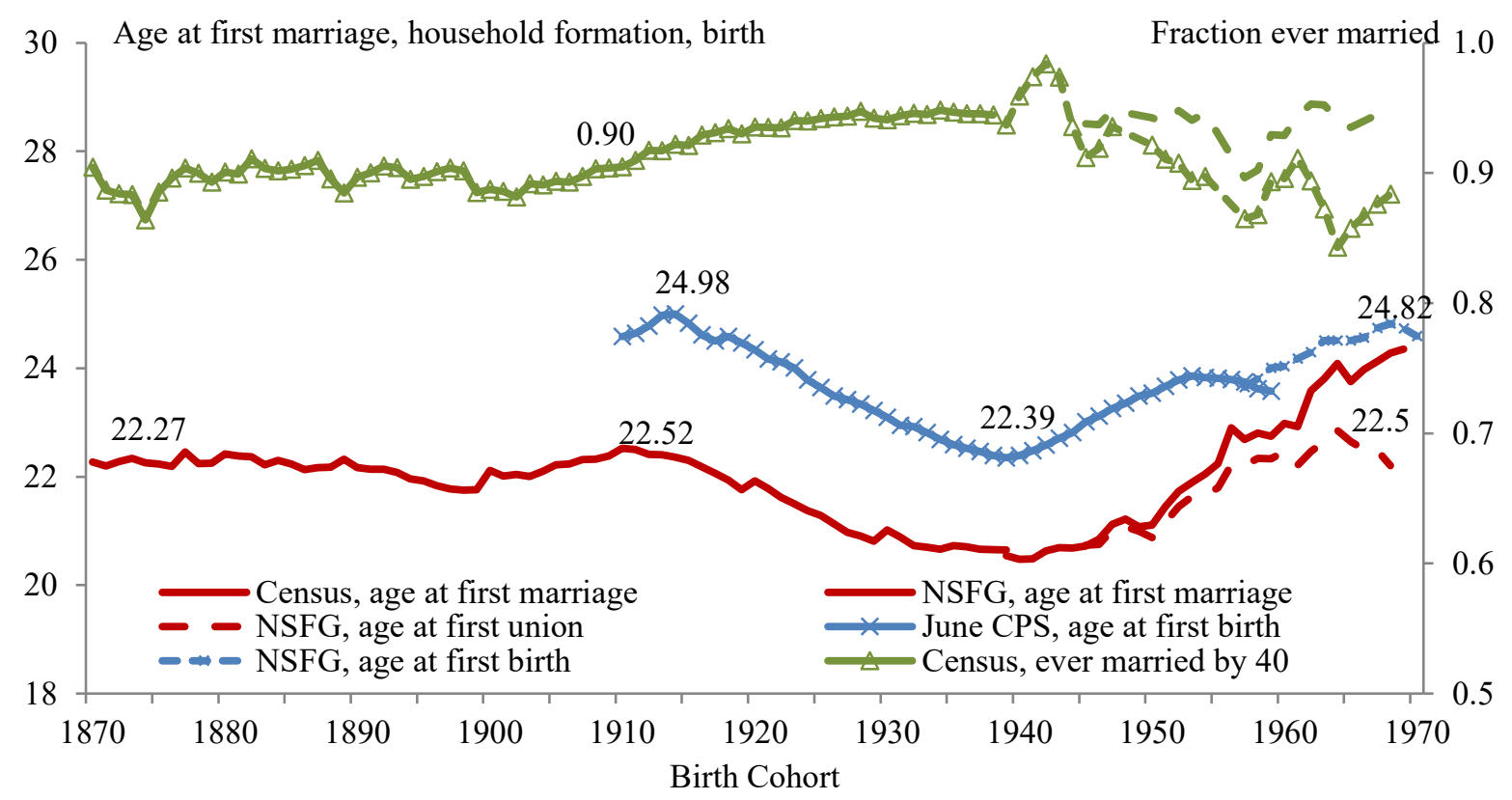

Notes: The figure plots the mean age at first marriage (conditional on ever married by age 39), first household formation or union (the younger of first marriage or first non-marital cohabitation), first birth (left vertical axis), and share ever married (right vertical axis) against single year-of-birth cohort. The National Survey of Family Growth (NSFG) and CPS trends are based on 3-year cohort moving averages. Sources: 1940-1980 decennial census IPUMS samples (Ruggles et al. 2010); 1979-1995 June CPS; 1982-2010 NSFG (Smock, Granda, and Hoelter 2013) . 


\section{References}

Ananat, Elizabeth Oltmans, Jonathan Gruber, and Phillip Levine. 2007. "Abortion Legalization and LifeCycle Fertility." Journal of Human Resources 42 (2):375-397.

Ananat, Elizabeth Oltmans, Jonathan Gruber, Phillip B. Levine, and Douglas Staiger. 2009. "Abortion and Selection." Review of Economics and Statistics 91 (1):124-136.

Ananat, Elizabeth Oltmans, and Daniel Hungerman. 2012. "The Power of the Pill for the Next Generation: Oral Contraception's Effects on Fertility, Abortion, and Maternal and Child Characteristics." Review of Economics and Statistics 94 (1):37-51.

Angrist, Joshua D., and William N. Evans. 1999. "Schooling and Labor Market Consequences of the 1970 State Abortion Reforms." In Research in Labor Economics, edited by Solomon Polachek, 75-113. Emerald Group Publishing.

Archuleta, Katherine. 2013. "Letter to Representative Chris Smith." Office of Personnel Management Accessed May $\quad 16, \quad 2017$. http://chrissmith.house.gov/uploadedfiles/opm_response_to_october_16_2013_letter.pdf.

Arcidiacono, Peter, Ahmed Khwaja, and Lijing Ouyang. 2012. "Habit Persistence and Teen Sex: Could Increased Access to Contraception Have Unintended Consequences for Teen Pregnancies?" Journal of Business and Economic Statistics 30 (2):312-325.

Atkins, Danielle N., and W. David Bradford. 2015a. "Association between Increased Emergency Contraception Availability and Risky Sexual Practices." Health Services Research 50 (3):809-829.

Atkins, Danielle N., and W. David Bradford. 2015b. "The Effect of Changes in State and Federal Policy for Nonprescription Access to Emergency Contraception on Youth Contraceptive Use: A Difference-in-Difference Analysis Across New England States." Contemporary Economic Policy 33 (3):405-417.

Bailey, Martha J. 2009. "Erratum and Addendum." Accessed September 2, 2015. http://wwwpersonal.umich.edu/ baileymj/Bailey_Erratum.pdf.

Bailey, Martha J. 2010. "'Momma's Got the Pill': How Anthony Comstock and Griswold v. Connecticut Shaped U.S. Childbearing." American Economic Review 100 (1):98-129.

Bailey, Martha J. 2006. "More Power to the Pill: The Impact of Contraceptive Freedom on Women's Lifecycle Labor Supply." Quarterly Journal of Economics 121 (1):289-320.

Bailey, Martha J. 2012. "Reexamining the Impact of U.S. Family Planning Programs on Fertility: Evidence from the War on Poverty and the Early Years of Title X." American Economic Journal: Applied Economics 4 (2):62-97. 
Bailey, Martha J., Melanie Guldi, Allison Davido, and Erin Buzuvis. 2011. "Laws and Policies Governing Contraceptive Access, 1960-1980." University of Michigan Working Paper. Accessed August 1, 2011. http://www-personal.umich.edu/ baileymj/ELA_laws.pdf.

Bailey, Martha J., Melanie Guldi, and Brad J. Hershbein. 2013. "Further Evidence on the Internal Validity of the Early Legal Access Research Design." Journal of Policy Analysis and Management 32 (4):899-904.

Bailey, Martha J., Melanie Guldi, and Brad J. Hershbein. 2014. "Is There a Case for a "Second Demographic Transition": Three Distinctive Features of the Post-1960 U.S. Fertility Decline." In Human Capital and History: The American Record, edited by Leah P. Boustan, Carola Frydman and Robert A. Margo. Cambridge, MA: National Bureau of Economics Research.

Bailey, Martha J., Brad J. Hershbein, and Amalia R. Miller. 2012. "The Opt-In Revolution? Contraception and the Gender Gap in Wages." American Economic Journal: Applied Economics 4 (3):225-54.

Bailey, Martha J., Olga Malkova, and Zoë McLaren. 2016. "Do Family Planning Programs Increase Children's Opportunities? Evidence from the War on Poverty and the Early Years of Title X." University of Michigan Working Paper. Accessed June 13, 2016. http://wwwpersonal.umich.edu/ baileymj/Bailey_Malkova_McLaren.pdf.

Becker, Gary S. 1991. A Treatise on the Family (Enlarged Edition). Cambridge, MA: Harvard University Press.

Bitler, Marianne P., and Madeline Zavodny. 2001. "The Effect of Abortion Restrictions on the Timing of Abortions." Journal of Health Economics 20 (6):1011-1032.

Blank, Rebecca M., Christine George, and Rebecca London. 1996. "State Abortion Rates: The Impact of Policies, Providers, Politics, Demographics, and Economic Environment." Journal of Health Economics 15 (5):513-553.

Boonstra, Heather D., Rachel Benson Gold, Cory L. Richards, and Lawrence B. Finer. 2006. "Abortion in Women's Lives." New York. Accessed May 16, 2017. https:/www.guttmacher.org/sites/default/files/pdfs/pubs/2006/05/04/AiWL.pdf.

Brandt, Allan M. 1985. No Magic Bullet: A Social History of Venereal Disease in the United States Since 1880. New York, New York: Oxford University Press.

Broughton, Hilary O., Christina M. Buckel, Karen J. Omvig, Jennifer L. Mullersman, Jeffrey F. Peipert, and Gina M. Secura. 2016. "From research to practice: dissemination of the Contraceptive CHOICE Project." Translational Behavioral Medicine:1-9. doi: 10.1007/s13142-016-0404-x.

Buckles, Kasey S., and Daniel M. Hungerman. 2016. "The Incidental Fertility Effects of School Condom Distribution Programs." NBER Working Paper No. 22322. 
Chung, Andrea Park, Martin Gaynor, and Seth Richards-Shubik. 2016. "Subsidies and Structure: The Lasting Impact of the Hill-Burton Program on the Hospital Industry." NBER Working Paper 22037.

Cintina, Inna. 2016. "Behind-the-Counter, but Over-the-Border? The Assessment of the Geographical Spillover Effects of Emergency Contraception on Abortions." Health Economics.

Cintina, Inna, and Morgen S. Johansen. 2015. "The Effect of Plan B on Teen Abortions: Evidence from the 2006 FDA Ruling." Contemporary Economic Policy 33 (3):418-433.

Committee on Adolescent Health Care. 2012. "Adolescents and Long-Acting Reversible Contraception: Implants and Intrauterine Devices." American College of Obstetricians and Gynecologists 539.

Cunningham, Scott, Jason M Lindo, Caitlin Myers, and Andrea Schlosser. 2017. "How Far is Too Far? New Evidence on Abortion Clinic Closures, Access, and Abortion Rates." NBER Working Paper 23366.

Current Population Survey. 2011. June Current Population Surveys: 1979-2010. Retrieved from: http://www.nber.org/data/current-population-survey-data.html

DiPrete, Thomas A., and Claudia Buchmann. 2013. The Rise of Women: The Growing Gender Gap in Education and What it Means for American Schools. New York, NY: Russell Sage Foundation Press.

Durrance, Christine P. 2013. "The Effects of Increased Access to Emergency Contraception on Sexually Transmitted Disease and Abortion Rates." Economic Inquiry 51 (3):1682-1695.

Easterlin, Richard A. 1975. "An Economic Framework for Fertility Analysis." Studies in Family Planning $6(3): 54-63$.

Easterlin, Richard A., and Eileen M. Crimmins. 1985. The Fertility Revolution: A Supply-Demand Analysis Chicago, IL: University of Chicago Press.

Easterlin, Richard A., Robert A. Pollack, and Michael L. Wachter. 1980. "Towards a More General Economic Model of Fertility Determination: Endogenous Preferences and Natural Fertility." In Population and Economic Change in Less Developed Countries, edited by Richard A. Easterlin. Chicago, IL: University of Chicago Press.

Ellwood, David T., and Christopher Jencks. 2004. "The Uneven Spread of Single-Parent Families: What Do We Know? Where Do We Look for Answers?" In Social Inequality 1, edited by Kathryn Neckerman, 3-77. New York: Russell Sage Foundation.

Finer, Lawrence B, Jenna Jerman, and Megan L Kavanaugh. 2012. "Changes in use of long-acting contraceptive methods in the United States, 2007-2009." Fertility and sterility 98 (4):893-897. 
Gerdts, Caitlin, Liza Fuentes, Daniel Grossman, Kari White, Brianna Keefe-Oates, Sarah E Baum, Kristine Hopkins, Chandler W Stolp, and Joseph E Potter. 2016. "Impact of Clinic Closures on Women Obtaining Abortion Services after Implementation of a Restrictive Law in Texas." American Journal of Public Health 106 (5):857-864.

Girma, Sourafel, and David Paton. 2011. "The impact of emergency birth control on teen pregnancy and STIs." Journal of Health Economics 30 (2):373-380.

Gold, Rachel Benson. 2003. "Lessons from Before Roe: Will Past be Prologue?" Guttmacher Report on $\begin{array}{lllll}\text { Public Policy. } & \text { Accessed } & \text { September } & 19,\end{array}$ https://www.guttmacher.org/sites/default/files/article files/gr060108.pdf.

Gold, Rachel Benson, and Elizabeth Nash. 2013. "TRAP Laws Gain Political Traction While Abortion Clinics - and the Women They Serve-Pay the Price." Guttmacher Policy Review 16 (2):7-12.

Goldin, Claudia. 2014. "A Grand Gender Convergence: Its Last Chapter." American Economic Review 104 (4):1091-1119.

Goldin, Claudia, and Lawrence F. Katz. 2002. "The Power of the Pill: Oral Contraceptives and Women's Career and Marriage Decisions." Journal of Political Economy 110 (4):730-770.

Goldthwaite, Lisa M., Lindsey Duca, Randi K. Johnson, Danielle Ostendorf, and Jeanelle Sheeder. 2015. "Adverse Birth Outcomes in Colorado: Assessing the Impact of a Statewide Initiative to Prevent Unintended Pregnancy." American Journal of Public Health 105 (9):e60-e66.

Graefe, Deborah R., and Daniel T. Lichter. 1999. "Life Course Transitions of American Children: Parental Cohabitation, Marriage, and Single Motherhood." Demography 36 (2):205-217.

Gross, Tal, Jeanne Lafortune, and Corinne Low. 2014. "What Happens the Morning After? The Costs and Benefits of Expanding Access to Emergency Contraception." Journal of Policy Analysis and Management 33 (1):70-93.

Grossman, Daniel, Sarah Baum, Liza Fuentes, Kari White, Kristine Hopkins, Amanda Stevenson, and Joseph E Potter. 2014. "Change in Abortion Services after Implementation of a Restrictive Law in Texas." Contraception 90 (5):496-501.

Gruber, Jonathan, Phillip Levine, and Douglas Staiger. 1999. "Abortion Legalization and Child Living Circumstances: Who Is the "Marginal Child"?" Quarterly Journal of Economics 114 (1):263-291.

Guldi, Melanie. 2011. "A Survey of the Literature on Early Legal Access to the Birth Control Pill and its Influence on Young Women's Fertility, Education, Career,and Labor Supply." In Research Handbook on the Economics of Family Law, edited by Lloyd R. Cohen and Joshua D. Wright, 271291. Northampton, MA: Edward Elgar.

Guldi, Melanie. 2008. "Fertility Effects of Abortion and Pill Access for Minors." Demography 45 (4):817827. 
Guttmacher, Alan. 1947. "Conception Control and the Medical Profession: The Attitudes of 3,381 Physicians toward Contraception and the Contraceptives They Prescribe." Human Fertility 12 (March):1-10.

Guttmacher Institute. 2016a. "Last Five Years Account for More Than One-quarter of All Abortion Restrictions Enacted Since Roe." Accessed January 13, 2016. https://www.guttmacher.org/article/2016/01/last-five-years-account-more-one-quarter-allabortion-restrictions-enacted-roe.

Guttmacher Institute. 2016b. "State Family Planning Funding Restrictions." Accessed February 3, 2017. https://www.guttmacher.org/print/state-policy/explore/state-family-planning-funding-restrictions.

Harper, Cynthia C., Corinne H. Rocca, Kirsten M. Thompson, Johanna Morfesis, Suzan Goodman, Philip D. Darney, Carolyn L. Westoff, and J. Joseph Speidel. 2015. "Reductions in Pregnancy Rates in the USA with Long-Acting Reversible Contraception: a Cluster Randomised Trial." The Lancet 386 (9993):562-568.

Henshaw, Stanley K., and Kathryn Kost. 2008. Trends in the Characteristics of Women Obtaining Abortions, 1974 to 2004. New York: Guttmacher Institute.

Hicks, Karen M. . 1994. Surviving the Dalkon Shield: Women v. the Pharmaceutical Industry. New York: Teachers College Press.

Hock, Heinrich. 2008. "The Pill and the College Attainment of American Women and Men." Florida State University Working Paper. Accessed September 14, 2016. ftp://econpapers.fsu.edu/RePEc/fsu/wpaper/wp2007_10_01.pdf.

Hotz, V. Joseph, and Robert A. Miller. 1988. "An Empirical Analysis of Life Cycle Fertility and Female Labor Supply." Econometrica 56 (1):91-118.

Hubacher, David, and Diana Cheng. 2004. "Intrauterine devices and reproductive health: American women in feast and famine." Contraception 69 (6):437-446.

Hutchings, Jane E., Patti J. Benson, Gordon W. Perkin, and Richard M. Soderstrom. 1985. "The IUD after 20 Years: A Review." Family Planning Perspectives 17 (6):250-255.

Jayachandran, Seema, Adriana Lleras-Muney, and Kimberly V. Smith. 2010. "Modern Medicine and the Twentieth Century Decline in Mortality: Evidence on the Impact of Sulfa Drugs." American Economic Journal: Applied Economics 2 (2):118-146.

Joyce, Ted, R. Tan, and Y. Zhang. 2013. "Abortion before \& after Roe." Journal of Health Economics 32 (5):804-815.

Kane, Thomas, and Douglas Staiger. 1996. "Teen Motherhood and Abortion Access." Quarterly Journal of Economics 111 (2):467-506. 
Karpilow, Quentin C., and Adam T. Thomas. 2016. "Reassessing the importance of long-acting contraception." American Journal of Obstetrics and Gynecology 216 (2):148.e1-148.e14.

Kearney, Melissa S., and Phillip Levine. 2009. "Subsidized Contraception, Fertility, and Sexual Behavior." Review of Economics and Statistics 91 (1):137-151.

Lesthaeghe, Ron J., and Lisa Neidert. 2006. "The Second Demographic Transition in the United States: Exception or Textbook Example? ." Population and Development Review 32 (4):669-698.

Lesthaeghe, Ron, and Dirk J. van de Kaa. 1986. "Twee demografische transities." In Bevolking: groei en krimp, 9-24. Deventer: Van Loghum Slaterus.

Levine, Phillip. 2003. "Parental Involvement Laws and Fertility Behavior " Journal of Health Economics $22(5): 861-878$.

Levine, Phillip B., Douglas Staiger, Thomas J. Kane, and David J. Zimmerman. 1999. "Roe v. Wade and American Fertility." American Journal of Public Health 89 (2):199-204.

Levine, Phillip, and Douglas Staiger. 2002. "Abortion as Insurance." NBER Working Paper 8813.

Levine, Phillip, Douglas Staiger, Thomas Kane, and David Zimmerman. 1996. "Roe v. Wade and American Fertility." NBER Working Paper 5615.

Lindo, Jason M., and Analisa Packham. forthcoming. "How Much Can Expanding Access To Long-Acting Reversible Contraceptives Reduce Teen Birth Rates." American Economic Journal: Economic Policy.

Lu, Yao, and David J.G. Slusky. 2016. "The Impact of Women's Health Clinic Closures on Fertility." Accessed December 22, 2016. http://slusky.ku.edu/wp-content/uploads/2016/09/LU-SLUSKY2016-Womens-Health-Clinic-Closures-and-Fertility-Sep-2016.pdf.

Martinez, Gladys, Kimberly Daniels, and Anjani Chandra. 2012. "Fertility of men and women aged 15-44 years in the United States: National Survey of Family Growth 2006-2010." Bethesda, MD: National Center for Health Statistics. Retrieved from: https://www.cdc.gov/nchs/data/nhsr/nhsr051.pdf.

McLanahan, Sara, and Tara Watson. 2011. "Marriage Meets the Joneses: Relative Income, Identity, and Marital Status " Journal of Human Resources 46 (3):482-517.

McNicholas, Colleen, Tessa Madden, Gina Secura, and Jeffrey F. Peipert. 2014. "The Contraceptive CHOICE Project Round Up: What we Did and What we Learned." Clinical Obstetrics and Gynecology 57 (4):635-643.

Mestad, Renee, Gina Secura, Jenifer Allsworth, Tessa Madden, Qiuhong Zhao, and Jeffrey Peipert. 2011. "Acceptance of long-acting reversible contraceptive methods by adolescent participants in the Contraceptive CHOICE Project." Contraception 84 (5):493-498. 
Michael, Robert T., and Robert J. Willis. 1976. "Contraception and Fertility: Household Production under Uncertainty." In Demographic Behavior of the Household, 25-98. Cambridge, MA: National Bureau of Economic Research.

Mooney, Christopher Z, and Mei-Hsien Lee. 1995. "Legislative morality in the American states: The case of pre-Roe abortion regulation reform." American Journal of Political Science 39 (3):599-627.

Mosher, William D, and Jo Jones. 2010. "Use of contraception in the United States: 1982-2008." Vital and health statistics. Series 23, Data from the National Survey of Family Growth (29):1-44.

Mulligan, Karen. 2016. "Access to emergency contraception and its impact on fertility and sexual behavior." Health economics 25 (4):455-469.

Myers, Caitlin. 2012. "Power of the Pill or Power of Abortion? Re-examining the Effects of Young Women's Access to Reproductive Control." IZA Discussion Paper no. 6661.

National Academy of Sciences. 1963. The Growth of World Population, Analysis of the Problems and Recommendations for Research and Training. Washington, D.C.: National Academies Press.

Nossiff, Rosemary. 2001. "Abortion Policy Before Roe: Grassroots and Interest-Group Mobilization." Journal of Policy History 13 (4):463-478.

Ott, Mary A., Gina S. Sucato, and Committee on Adolescence. 2014. "Contraception for Adolescents." Pediatrics 134 (4).

Packham, Analisa. 2016. "Family Planning Funding Cuts and Teen Childbearing." Accessed May 16, 2017. http://www.academia.edu/19435560/Family_Planning_Funding_Cuts_and Teen_Childbearing.

Peipert, Jeffrey F., Tessa Madden, Jenifer E. Allsworth, and Gina M. Secura. 2012. "Preventing unintended pregnancies by providing no-cost contraception." Obstetrics \& Gynecology 120 (6):1291-1297.

Raymond, Elizabeth, James Trussell, and Chelsea B Polis. 2007. "Population Effect of Increased Access to Emergency Contraceptive Pills: A Systematic Review." Obstetrics \& Gynecology 109 (1):181188.

Reagan, Leslie. 1997. When Abortion Was a Crime: Women, Medicine, and Law in the United States, 18671973. Berkeley: University of California Press.

Ricketts, Sue, Greta Klingler, and Renee Schwalberg. 2014. "Game Change in Colorado: Widespread Use Of Long-Acting Reversible Contraceptives and Rapid Decline in Births Among Young, LowIncome Women." Perspectives on Sexual and Reproductive Health 46 (3):125-132.

Rotz, Dana, Dara Lee Luca, Brian Goesling, Elizabeth Cook, Kelly Murphy, and Jack Stevens. 2016. Final Impacts of the Teen Options to Prevent Pregnancy Program. Cambridge, MA: Mathematica Policy Research. 
Ruggles, Steven J, Trent Alexander, Katie Genadek, Ronald Goeken, Matthew B Schroeder, and Matthew Sobek. 2010. Integrated public use microdata series: version 5.0 [Machine-readable database]. Retrieved from: www.ipums.org

Salganicoff, Alina, Adara Beamesderfer, Nisha Kurani, and Laurie Sobel. 2014. Coverage for Abortion Services and the ACA: Henry J. Kaiser Family Foundation.

Secura, Gina M., Jenifer E. Allsworth, Tessa Madden, Jennifer Mullersman, and Jeffrey F. Peipert. 2010. "The Contraceptive CHOICE Project: reducing barriers to long-acting reversible contraception " American Journal of Obstetrics and Gynecology 203 (2):115.e1-115.e7.

Selzer, Judith A., and Susan M. Bianchi. 2013. "Demographic Change and Parent-Child Relationships in Adulthood." Annual Review of Sociology 39:275-290.

Smith, Tom W, and Jaesok Son. 2013. "Trends in Public Attitudes towards Abortion." The National Opinion Research Center, May. Accessed May 16, 2017. http://www.norc.org/PDFs/GSS\%20Reports/Trends\%20in\%20Attitudes\%20About\%20Abortion Final.pdf.

Smock, Pamela J., Peter Granda, and Lynette Hoelter. 2013. Integrated Fertility Survey Series, Release 7, 1955-2002 [United States]. ICPSR26344-v7. Retrieved from: http://doi.org/10.3886/ICPSR26344.v7

Stevenson, Betsey, and Justin Wolfers. 2006. "Bargaining in the Shadow of the Law: Divorce Laws and Family Distress." Quarterly Journal of Economics 121 (1):267-288.

Tavernise, Sabrina. 2015. "Colorado Finds Startling Success in Effort to Curb Teenage Births." New York Times, July 5. http://www.nytimes.com/2015/07/06/science/colorados-push-against-teenagepregnancies-is-a-startling-success.html? $\mathrm{r}=0$.

The American Law Institute. 1962. "Model Penal Code Proposed Official Draft, 1962." http://home.heinonline.org/titles/American-Law-Institute-Library/Model-Penal-Code/?letter=M.

Thomasson, Melissa A., and Jaret Treber. 2008. "From Home to Hospital: The Evolution of Childbirth in the United States, 1928-1940." Explorations in Economic History 45 (1):76-99.

Thomsen, Russel J. 1982. An atlas of intrauterine contraception. Washington: Hemisphere Publishing Corporation.

Tone, Andrea. 2001. Devices and Desires: A History of Contraceptives in America New York, NY: Hill and Wang.

Weinberg, Roy. 1968. Laws Governing Family Planning, Legal Almanac Series no. 18. Dobbs, Ferry, N.Y.: Oceana Publications. 
Westoff, Charles F. 1976. "Trends in Contraceptive Practice: 1965-1973." Family Planning Perspectives 8 (1):54-57.

Westoff, Charles F. 1975. "The Yield of the Imperfect: The 1970 National Fertility Study." Demography 12 (4):573-580.

Wilmoth, John R. 1995. "Arguments and Action in the Life of a Social Problem: A Case Study of 'Overpopulation,' 1946-1990." Social Problems 42 (3):318-343.

Wilmoth, John R., and Patrick Ball. 1992. "The Population Debate in American Popular Magazines, 194690." Population and Development Review 18 (4):631-668.

Yuzpe, A. Albert, HJ Thurlow, I. Ramzy, and J.I. Leyshon. 1974. "Post coital contraception-A pilot study." Journal of Reproductive Medicine 13 (2):53-58.

Zuppann, Andrew C. 2011. "The Impact of Emergency Contraception on Dating and Marriage." Accessed May 15, 2017. http://www.uh.edu/econpapers/RePEc/hou/wpaper/201310815.pdf. 